\title{
The Meaningful Votes: Voting on Brexit in the British House of Commons
}

\author{
Toke Aidt ${ }^{1,2,5}$ (D) $\cdot$ Felix Grey ${ }^{1,3} \cdot$ Alexandru Savu $^{1,4}$
}

Received: 19 August 2019 / Accepted: 3 December 2019 / Published online: 14 December 2019

(c) The Author(s) 2019

\begin{abstract}
Why do politicians rebel and vote against the party line when high stakes bills come to the floor of the legislature? To address that question, we leverage the three so-called Meaningful Votes that took place in the British House of Commons between January and March 2019 on the Withdrawal Agreement that the Conservative government had reached with the European Union. The bill was defeated decisively three times following a major revolt amongst Conservative backbench Members of Parliament (MPs). We find that three factors influenced their rebellion calculus: the MP's own ideological views, constituency preferences and career concerns. Somewhat paradoxically, the rebellion within the Conservative Party came from MPs who had supported Leave in the 2016 Brexit referendum and from MPs elected in Leave-leaning constituencies.
\end{abstract}

Keywords Brexit $\cdot$ Roll call votes $\cdot$ Rebels $\cdot$ Party discipline $\cdot$ Party coherence $\cdot$ House of Commons

\section{JEL Classification D72}

\section{Introduction}

In January 2019 the United Kingdom's Conservative government led by Prime Minister Theresa May suffered the worst defeat ever recorded in the history of the House of Commons. Its flagship policy, leaving the European Union (EU) in a way that compromised between the polarized "Hard Brexit" and "Remain" factions in Parliament, was defeated by 432 to 202 votes, a majority of 230 . The principal reason for the defeat was a huge rebellion by 118 Conservative Members of Parliament (MPs). In March the government held

Toke Aidt

tsa23@econ.cam.ac.uk

1 Faculty of Economics, University of Cambridge, Cambridge, UK

2 Jesus College, University of Cambridge, Cambridge, UK

3 Corpus Christi College, University of Cambridge, Cambridge, UK

4 Fitzwilliam College, University of Cambridge, Cambridge, UK

5 CESifo, Munich, Germany 
two further votes, on the same policy, and again lost by large margins: 149 and 58. Two months later the Prime Minister announced her resignation.

Those three so-called Meaningful Votes on May's Withdrawal Agreement rank among the great votes of British parliamentary history. They echo the vote on the repeal of the Corn Laws, which put an end to trade protection of agricultural products and split the Tory party in 1846 (Schonhardt-Bailey 2006), and also the Great Reform Act, which altered the system of parliamentary representation in 1832, with Tory MPs who broke the party line playing a pivotal role (Aidt and Franck 2013, 2019). It is historically very rare for a UK government to lose with more than 100 votes on a key piece of legislations. The last time was in 1924, when the minority Labour government of Ramsay MacDonald was defeated by margins of 166, 161 and 140 .

In this paper, we seek to explain why Conservative MPs rebelled and understand what drove their individual decisions not to toe the party line. We argue that the three Meaningful Votes potentially can provide valuable general insights into why MPs rebel against their leaders and why the organizational structures and mechanisms that normally ensure party discipline and unity occasionally break down, resulting in the government being "rolled" and losing important votes. The sequence of Meaningful Votes has at least four appealing features that allow us to do just that. First, as already noted, it is rare that a high stakes government bill is defeated so decisively. Second, it was not a so-called free vote on which the party leaders allow their co-partisan MPs to vote as they like. On the contrary, both the Conservative Party and the Labour Party "whipped", demanding that MPs toe the respective party lines. It thus was not costless for MPs to rebel. Third, as a consequence of the 2016 Brexit referendum, we, uniquely, observe revealed preferences on the question of leaving the EU for each MP (we know how they voted and campaigned) and for their voters in each of Britain's 650 parliamentary constituencies (we know the shares voting Leave and Remain). Fourth, the MPs effectively voted on the same bill three times, which also is highly unusual. That information enables us to develop an innovative test of career concerns.

The purpose of the paper is, therefore, two-fold. First, we want to document the correlates underlying the mass rebellion against the Withdrawal Agreement (May's deal) inside the Conservative Party. Second, we want to leverage the unique features of the sequence of Meaningful Votes to test the "tripartite model" of party rebellion (Muller and Strom 1999). The model, which we outline in Sect. 4, postulates that an MP's voting decision is a function of three potentially conflicting factors: the MP's own preferences (his or her ideology), political career concerns, and the preferences of their constituents. The fact that we observe plausible proxies for the revealed preference of the MPs and their constituents enables us to contribute to the extensive literature on party discipline and rebellion (see Kam 2014; Kirkland and Slapin 2018).

Our inquiry into the rebellion amongst Conservative backbench MPs yields the following insights. First, we find evidence that MPs were influenced by their own preferences, career concerns and constituency preferences, but that their own preferences were almost twice as important as the other two factors. Specifically, MPs who had voted and campaigned against leaving the EU in the referendum (Remain MPs) were almost 40 percentage points more likely to support May's deal than other (Leave) MPs, while MPs representing constituencies with (one standard deviation) more Leave voters were 17 percentage points less likely to support the deal. MPs mindful of their career prospects under a May government were about 20 percentage points more likely to support May's deal. We also present (suggestive) evidence that the prospect of promotion to posts in a future government motivated the MPs. Somewhat paradoxically, the rebellion within the Conservative 
Party that defeated May's deal in the House of Commons three times in a row originated from MPs who had supported Leave in the referendum and from MPs elected in Leave leaning constituencies. Second, we find that the effects are heterogeneous across different sub-samples of MPs in theoretically interesting ways. MPs elected to safe seats placed more weight on career concerns than MPs elected in marginal seats who placed more weight on constituency preferences in their rebellion calculus. Leave MPs but not Remain MPs were motivated by constituency preferences. That conclusion consistent with two types of grandstanding: Leave MPs could signal "ideological purity" to their Leave voters by opposing May's deal; Remain MPs could pander to their Leave voters by "converting" and voting for May's deal. MPs with a history of rebellion did not weight career concerns differently from party loyalists in their voting calculus.

The rest of the paper is organized as follows. Section 2 offers a short literature review that places our study in context. Section 3 sets out the background to the three Meaningful Votes. Section 4 presents the "tripartite" model of partisan rebellion. Section 5 presents the data. Section 6 explains our estimation strategy. Section 7 presents the results. Section 8 concludes.

\section{Literature review}

Our analysis of the sequence of Meaningful Votes contributes to two main strands of literature. First, we contribute to the literature on party discipline and roll call rebels (for overviews, see Kirkland and Slapin 2018 or Kam 2014). The central question in that literature is why individual politicians decide to defy the political party to which they belong and vote against the party's agreed policy in roll call votes or parliamentary divisions (as they are known in the UK). Krehbiel (1993) views rebellions as a competition between politicians' ideological preferences, their concern about re-election, and their loyalty to their party. Loyalty may, in turn, be induced by political career concerns (Muller and Strom 1999) or through a process of political socialization (Crowe 1986). We build on that theoretical framework. Empirical work has focused on the United States where roll call rebellion is widespread and it is common for moderate legislators to "cross the aisle" (e.g., Kirkland and Slapin 2018). However, in spite of greater party discipline in many parliamentarian systems, it is not uncommon for individual "backbench" politicians (i.e., those with no positions in government) to revolt against their party in many other countries too (e.g., Kam 2009; Morgenstern 2003; Carey 2008; Hix et al. 2007; Kauder et al. 2017). Unlike in US politics, however, in the United Kingdom and elsewhere discipline-breakers tend to be politicians with ideologically extreme views (Kam 2009), and they belong mainly to the governing party (Kirkland and Slapin 2018). The available evidence suggests that voters pay some attention to how their representatives vote, at least when the issue is controversial, and that they reward them for rebelling (e.g., Longley 1998; Johnston et al. 2002; Pattie et al. 1994; Bertelli and Dolan 2009; Vivyan and Wagner 2012; Campbell et al. 2019). The evidence also shows that career concerns play a role (e.g., Benedetto and Hix 2007; Eggers and Spirling 2018) although the evidence on whether parties actually punish individual politicians for voting against the party line is mixed (Eggers and Spirling 2016; Kauder et al. 2017). We contribute to that empirical literature by studying how ideology, career concerns and voter preferences shaped the pattern of rebellion within the Conservative Party in the British House of Commons on an especially high stakes bill. In particular, we are able to leverage the fact that we have plausible measures of both MP 
and voter preferences on the issue to evaluate the relative importance of the three forces that generally influence a politician's decision to rebel.

Second, our analysis contributes to the fast emerging literature on the causes of the Brexit referendum result itself. ${ }^{1}$ Becker et al. (2017), Arnorsson and Zoega (2018), Zhang (2018) and Fidrmuc et al. (2019) use aggregate vote share results at the local authority, constituency or ward level to study the socio-economic correlates of the Leave vote share. Four groups of correlates were important. The first group includes indicators of socio-economic deprivation. The Leave vote share was high in areas with low levels of education, low incomes, historical reliance on manufacturing employment, and high unemployment rates (Becker et al. 2017). The second group includes demographic factors. Areas with large proportions of British male adults and with high proportions of elderly voters predominately voted Leave (Zhang 2018). The third group of correlates relates to immigration, which played an important role for the rhetoric of the referendum campaign. Areas with high net immigration were more likely to vote Leave (Arnorsson and Zoega 2018). The final group of correlates relates to the direct benefits an area has received over the years from the EU's Cohesion Fund. ${ }^{2}$ Areas that received more money from the Cohesion Fund were moderately more supportive of Remain, but this effect is dwarfed by the fact that those areas had low turnouts in the referendum (Fidrmuc et al. 2019).

It is, of course, always a danger trying to infer individual vote intentions from aggregate vote share data (the ecological fallacy), so the correlations should be interpreted with caution. A better approach is to examine individual-level survey data and a number of studies have done so previously. They largely confirm what the correlations reported above suggest. Alabrese et al. (2019), for example, find that voting Leave is associated with older age, white ethnicity, low educational attainment, infrequent use of smartphones and the internet, receiving public benefits, adverse health, and low life satisfaction. Others have found that negative attitudes towards immigration increase the probability that an individual voted Leave (Arnorsson and Zoega 2018) and that the generational divide-younger individuals are less Eurosceptical than older ones-reflects a combination of individuals' experience of the EU during their formative years and differences in access to education for different generations (Fox and Pearce 2018). Another approach to understanding why many voters supported Leave in the referendum is to study support for the United Kingdom Independence Party (UKIP) — a single-issue party that since the 1990s has campaigned for the United Kingdom to leave the European Union. Using within individual variation in exposure to welfare cuts, Fetzer (2019) shows that individuals were more likely to "feel close" to UKIP after they were affected personally by the government's austerity program. Insofar as UKIP support is a good proxy for how an individual voted in the 2016 referendum, the results suggest that austerity played a major role in bringing about the referendum result. In conclusion, the evidence, both from the analysis of aggregate vote share data and from the analysis of individual vote choices, suggest that socio-economic deprivation, austerity, demographics, and attitudes to immigration contributed to the referendum result favoring Leave. We add to that literature by studying another aspect of the Brexit processthe sequence of Meaningful Votes. This provides new insights into the link between the

\footnotetext{
1 See Clarke et al. (2017) for a comprehensive analysis of the Brexit referendum and its background.

2 The Cohesion Fund redistribute funds from the EU budget to Member States whose Gross National Income (GNI) per inhabitant is less than $90 \%$ of the EU average. It aims at reducing economic and social disparities.
} 
referendum result in particular constituencies and the ways in which the MPs elected in those constituencies behaved in Parliament.

\section{The narrative: What actually happened?}

The relationship with Europe has been a major issue for the UK's center-right Conservative Party for the past 50 years. The UK joined the EU in 1973 under a Conservative government, but with a broad base of political support: in a 1975 referendum on EU membership $67 \%$ of voters and all major political parties supported joining. ${ }^{3}$ However, over the next 40 years, the EU moved from being primarily a trading bloc, to a much closer economic and political union. That process was bitterly, but unsuccessfully, opposed by a minority of Conservative Party MPs, especially in the early 1990s when the Maastricht Treaty (an expansion of EU powers with a corresponding loss of UK sovereignty) came into force (Sowemimo 1996). In parallel to those events, a minority of generally right-leaning voters favoured leaving the EU. Support for that position grew in response to migration from Eastern European countries that joined the EU from 2004 onwards. The United Kingdom Independence Party (UKIP), a single issue party advocating the UK's departure from the EU, began to gain significant support, principally at the expense of the Conservative Party: in EU Parliamentary elections, UKIP came third in 2004, second in 2009 and first in 2014 (e.g., Clarke et al. 2016).

In an attempt to both neutralize growing voter support for UKIP and deal with internal divisions in the Conservative Party, Conservative Prime Minister David Cameron offered a referendum on EU membership as part of his re-election campaign in 2015, alongside an attempt to renegotiate the UK's relationship with the EU. ${ }^{4}$ In the short run, the policy was a successful: somewhat against expectations the Conservatives won the 2015 election and UKIP support collapsed. In order to achieve Cameron's second aim of mending divisions within the Conservative Party, he allowed his MPs to campaign for either side in the 2016 referendum, rather than requiring them to toe the party line and support continued membership in the EU ("Remain"). A significant minority of both backbench and frontbench, i.e., those serving in the government, Conservatives campaigned subsequently for exiting the EU ("Leave"). The referendum was held on 23 June 2016, and resulted in an unexpected victory for Leave, with $52 \%$ of the vote (and considerable geographic and demographic heterogeneity; see Becker et al. 2017). Cameron resigned immediately, and was replaced as Prime Minister by Conservative MP Theresa May, who began the process of withdrawing from the EU. Under EU law, a member state can leave the union by triggering Article 50 of the Lisbon Treaty. That provision gives that member state up to two years to negotiate a Withdrawal Agreement with the EU, which sets out the terms under which it leaves (covering everything from future customs arrangements to past pension liabilities). If no agreement is in place at the two-year deadline, the member state can leave without an

\footnotetext{
3 At the time the bloc was called the EEC (European Economic Community), becoming the EU in 1993. For simplicity this article uses EU throughout.

${ }^{4}$ Bernholz et al. (2004) propose a reform of EU institutions that would protect the subsidiarity principle and create effective checks and balances by breaking the Commission's agenda monopoly. If that proposal had been adopted in the mid-2000s, the critique levied against the EU by many British euro-sceptics regarding the risk of an EU super state and democratic deficits would have been answered.
} 
Table 1 Breakdown of the Meaningful Votes by Party and Govt. Positions

\begin{tabular}{|c|c|c|c|c|c|c|c|c|c|}
\hline & \multicolumn{3}{|c|}{ First vote } & \multicolumn{3}{|c|}{ Second vote } & \multicolumn{3}{|c|}{ Third vote } \\
\hline & For & Against & Abstain & For & Against & Abstain & For & Against & Abstain \\
\hline \multicolumn{10}{|c|}{ Panel A-Vote by Party } \\
\hline Conservative & 196 & 118 & 3 & 235 & 78 & 4 & 277 & 37 & 3 \\
\hline Labour & 3 & 248 & 5 & 4 & 247 & 5 & 6 & 243 & 7 \\
\hline LD & 0 & 11 & 0 & 0 & 11 & 0 & 0 & 11 & 0 \\
\hline SNP & 0 & 35 & 0 & 0 & 35 & 0 & 0 & 34 & 1 \\
\hline DUP & 0 & 10 & 0 & 0 & 10 & 0 & 0 & 10 & 0 \\
\hline Other & 3 & 10 & 8 & 3 & 10 & 8 & 3 & 9 & 9 \\
\hline Total & 202 & 432 & 16 & 242 & 391 & 17 & 286 & 344 & 20 \\
\hline \multicolumn{10}{|c|}{ Panel B-Conservatives by Govt. Position } \\
\hline Frontbench & 93 & 0 & 2 & 93 & 0 & 2 & 93 & 0 & 2 \\
\hline Backbench & 103 & 118 & 1 & 142 & 78 & 2 & 184 & 37 & 1 \\
\hline Total & 196 & 118 & 3 & 235 & 78 & 4 & 277 & 37 & 3 \\
\hline
\end{tabular}

Frontbench MPs hold government posts; backbench MPs do not. SNP is the Scottish National Party; DUP is the Democratic Unionist Party; LD is the Liberal Democrats. The four Conservative MPs who abstained were the two Whips, the Deputy Speaker and, in the second vote, MP Douglas Ross (who ended up voting with the government in the third vote); the Whips served as Tellers and, as such, they are not counted in the totals of those voting for or against a motion and we include them amongst those who abstained; the Speaker and the Deputy Speaker traditionally abstain on all votes. We record the MPs as belonging to the party that they belonged to in January 2019 (before the first Meaningful Vote), but note that ten MPs (three Conservative MPs and seven Labour MPs) resigned from their respective parties between the first and the second Meaningful Vote. For the purpose of the statistical analysis, it does not make any difference if we eliminate the three Conservative MPs who resigned from the sample for the second and third vote

agreement, or can ask for an extension of the negotiating period, during which the country remains part of the EU.

Over the course of the two-year UK-EU negotiation of the Withdrawal Agreement, divisions within the Conservative Party deepened. On one side, many Leavers became "Hard Brexiteers", such as senior government minister Boris Johnson and members of the European Research Group (ERG), who increasingly favoured a policy of little or no future cooperation with the EU ("no deal"). On the other side, a smaller group of former Remainers favored a "Soft Brexit", a close future relationship with the EU resembling full membership. In November 2018, the final Withdrawal Agreement was struck between May and the EU. Although that did not specify all aspects of the future UK-EU relationship, generally speaking it was a compromise somewhere between Hard and Soft Brexit. Over the course of the negotiations, Johnson and several other high profile Hard Brexiteer government ministers resigned in protest at compromises made by May.

The final step was for Parliament to pass the Withdrawal Agreement. That requirement itself was the result of an earlier parliamentary setback for May, when MPs succeededagainst the wishes the government-in securing a "Meaningful Vote" on whatever terms the UK eventually left the EU on. Five full days of parliamentary debate were set aside, with the vote to be held on 11 December 2018. The Whips, MPs whose jobs it is to ensure internal party discipline, worked hard to persuade potential rebels to back the government. The main tool at their disposal is the prospect of future promotion in government. Over the course of the debate, it became clear that May was not going to win the vote, so she 
delayed it to 15 January 2019, in an attempt to buy more time in which to persuade potential rebels. That strategy was not successful: the first Meaningful Vote was lost by the government by 432 to 202 votes, a majority of 230 , representing the most serious defeat of a UK government in the history of Parliament.

Table 1 shows the breakdown of MPs' votes on the three Meaningful Votes by party (panel A) and for the Conservative Party between front- and backbenchers (panel B). From these data, we see that a number of factors contributed to May's defeat. The Democratic Unionist Party (DUP) — a socially conservative, pro-Brexit, Northern Irish party—which had agreed to support the Conservative government (having lost its majority in the 2017 general election), but rebelled because in their view the Withdrawal Agreement treated Northern Ireland differently to the rest of the UK (related to the so-called Irish backstop problem). Very few pro-Brexit MPs from the center-Left opposition Labour Party ended up supporting the government. ${ }^{5}$ The centrist Liberal Democrats (LD) and center-left Scottish National Party (SNP) opposed the government unanimously, but that opposition had been anticipated. By far the main factor behind May's defeat was the huge scale of the rebellion by her own backbench MPs. The frontbenchers with government posts, on the other hand, toed the line and none of them rebelled (Table 1, panel B).

After the vote, the EU refused to renegotiate the Withdrawal Agreement; under Article 50, time was running out before the UK would either have to ask for an extension (politically very costly for the Conservatives) or leave without a deal (economically very costly for the country). May, therefore, held a Second Meaningful Vote on 12 March 2019, essentially a repeat vote on the policy that had been rejected two months before (some minor changes in interpretation of certain aspects of it were introduced). May and her Whips worked hard to persuade rebel Conservative MPs, but again unsuccessfully: the government lost by 391 to 242 votes, a majority of 149 . Following that defeat, she asked the EU for an extension, rather than leaving with no deal at end of March.

On the day the UK originally was supposed to leave the EU, May held a Third Meaningful Vote, again on essentially the same Withdrawal Agreement. She and her Whips made a final push to persuade rebels, increasingly with the threat to Hard Brexiteers that Brexit may not happen at all if the Withdrawal Agreement was not passed. Again, the government lost, although it cut its margin of defeat, from 344 to 286 votes, a majority of 58. Boris Johnson was the most prominent rebel to change his mind, and vote with the government for the first time on that final vote.

Immediately after losing the third vote, May had to ask the EU for another extension of Article 50, a further major political humiliation. In local and EU elections in May 2019, the Conservatives did exceptionally badly. With the central policy of the government in disarray and her party falling apart, the Prime Minister announced her resignation on 24 May 2019. ${ }^{6}$

\footnotetext{
${ }^{5}$ Some predictions at the time of the first vote had up to 30 Labour MPs intending to vote with the government. More generally, Brexit has produced serious internal divisions in the Labour Party, although they did not have a major impact on the Meaningful Votes. Hence, this article focuses on the Conservative Party.

${ }^{6}$ Three major aspects of the breakdown the Conservative party's unity were the following. May suffered a large number of resignations of both junior and senior ministers: from 11 June 2017 onwards, 33 ministers resigned over Brexit. Four Conservative MPs also defected from the party over Brexit, either to new parties or to sit as independents. On 11 December 2018, the day the first Meaningful Vote originally was to be held, Theresa May faced an internal Conservative Party vote of No Confidence, brought by Hard Brexit ERG (European Research Group) members, which she defeated.
} 
Johnson, the frontrunner to replace May among Conservative Party members (who select the party leader), won the ensuing leadership contest and became Prime Minister in July 2019. A proponent of Hard Brexit, he replaced much of May's relatively balanced government with a group of Hard Brexiteers in all of the most senior government posts. Johnson negotiated some changes to the Withdrawal Agreement concerning the Irish backstop, and on 22 October 2019 MPs passed a second reading of the resulting bill by a majority of 30. However, they also voted down Johnson's attempt to rush through the legislation in time for him not to have to extend the UK's membership of the EU past 31 October (politically costly for Johnson after his 'do or die' commitment to leaving before that date). Hence, Johnson pushed for and eventually obtained a general election on 12 December 2019. The parliament that rejected May's deal three times, therefore, never got a chance to have a final say on Johnson's deal: passing a second reading does not indicate that the bill necessarily would have become law. Many MPs who voted for it at the second reading, for example, were said to be planning amendments radically to soften the deal in ways Johnson had categorically ruled out.

\section{Theoretical framework}

In this section, we develop a theoretical framework that explains why politicians (henceforth MPs) may decide to vote against their own party's policy, and which we use to structure our empirical investigation of the Meaningful Votes. For that reason, we formulate the framework with reference to the Westminster system. This system is characterized by a high level of party unity in general, a clear government-opposition divide, agenda control monopolized by the Cabinet within the governing party, and MPs elected in single-member districts with local party organizations having significant input into who is selected to represent the constituency (e.g., Baughman 2004). ${ }^{7}$

MPs are members of political parties and are elected under those party labels and on the party manifesto. The members share policy preferences and have common goals, but only up to a point. Within a party, in general, substantial preference heterogeneity on particular issues exists, with extreme and moderate MPs both belonging to the same party. Such heterogeneity creates a fundamental tension for party members between supporting the party's policy (selected by the party leadership), which will appeal to some but not to all, and pursuing their own preferred policy. Party leaders are, of course, well aware of that tension and will seek to devise incentives and rules to enforce party discipline, create party coherence and avoid mass rebellion on critical bills (Kam 2014). Party leaders can, in principle, pursue that goal by controlling the selection of candidates to be fielded (select only candidates who will toe the party line), by controlling the policy agenda (make sure that

\footnotetext{
7 Broader legislative institutions and party structures help shape the costs and benefits for politicians to deviate from the party line, along with the constraints that party leaders face in creating party coherence (Krehbiel 1993). The differences, for example, between a Westminster-type system and a US-type system often are emphasised (Gaines and Garrett 1993). Stratmann (2006) leverages the mixed plurality and proportional election system in Germany to show that federal politicians who are elected under plurality rule from single member districts are more likely than those elected on a party list under proportional representation to vote against party lines in roll call votes. For a comparative study of the UK and the US, see Kirkland and Slapin (2018) and for a study of the European Parliament see Benedetto and Hix (2007). For a study of the consequences of government ideology, see Aidt et al. (2018).
} 
proposals are agreeable to most party members), by fostering socialization (Crowe 1986), and by sharing and withholding the perks of public office strategically.

Building on Muller and Strom (1999)'s tripartite model, we make a distinction between three factors that affect an MP's decision to rebel against his or her party. The first consideration is ideology: MPs care about policy and their position on a particular issue often deviates from the party's official stance. That gap may motivate an MP to rebel. The second consideration is career concerns: MPs usually want a legislative career. In the Westminster system, where agenda control is monopolized by the Cabinet, political promotion is about government posts for members of the governing party and about posts in the shadow cabinet for opposition MPs. Such allocation procedures make rebellion costly for backbenchers as well as for frontbenchers (those with government or shadow government posts) because party leaders can withhold promotion for rebellious backbenchers and demote frontbenchers who do not toe the line. ${ }^{8}$ The third consideration is constituency preferences and re-election. In the Westminster system, MPs are elected to represent the voters in their constituency. As argued by, for example, Gaines and Garrett (1993), Kirkland and Slapin (2018), Kam (2009) and many others, MPs in that system have an incentive, albeit not necessarily as strong an incentive as US legislators, to develop a persona independent of their party that connects them with their constituents and their local party organization. They can do so publicly by deviating from their party's policy on issues that their voters and selectors in the local party organization care particularly about in parliamentary divisions. Such grandstanding signals their ideological purity, integrity or trustworthiness, gets them media exposure and can potentially insulate them from the electoral unpopularity (in their constituency) of the party's policy. ${ }^{9}$

Within the public choice tradition, MPs are viewed as rational decision makers who need to navigate the foregoing three considerations when they decide if they should rebel on a particular issue. More often than not, the forces pull in different directions and MPs find themselves in the cross fire at the center of a triangle with their voters, their ideological conviction, and their party (Hix et al. 2007; Morgenstern 2003; Saiegh 2011). Figure 1 illustrates this tripartite model of roll call voting.

The costs and benefits of rebellion differ systematically between the governing and opposition parties on the one hand, and within the governing party (or coalition) between the frontbenchers with government posts and backbenchers without on the other. First, with regard to the government-opposition split, Kirkland and Slapin (2018) argue that it is MPs with extreme preferences (far from the center) within the governing party that stand to benefit the most from rebellion. That is because they can signal to their constituents that they are "ideologically pure" by voting against the party line and expect to be rewarded

\footnotetext{
8 Bertelli and Dolan (2009) present evidence from intervention in House of Commons's debates related to health care that is consistent with political careerism. The evidence on whether party leaders in actual fact punish rebels by denying them promotion is mixed. Eggers and Spirling (2016) study over 20,000 parliamentary divisions that took place between 1836 and 1910 in the British House of Commons and show that more loyal MPs were more likely to obtain ministerial posts. In contrast, Kauder et al. (2017) study 218 roll call votes in the German federal parliament (Bundestag) and ask if rebels are punished by party leaders by being allocated a less attractive position on the party list in the next election. They find that parties do not punish politicians who have voted against the party line in that way.

${ }^{9}$ Campbell et al. (2019) and Vivyan and Wagner (2012) present evidence from the UK that deviating from the party line can help MPs seeking re-election. Pattie et al. (1994) show that rebellion on high profile issues, such as capital punishment or the poll tax, had affected the re-election prospects of the rebels, but otherwise they find no discernible consequences. Ragusa (2016) shows that US legislators take more extreme positions if they won election to the Senate after representing a highly partisan state.
} 
Fig. 1 The MPs in crossfire: the tripartite model.

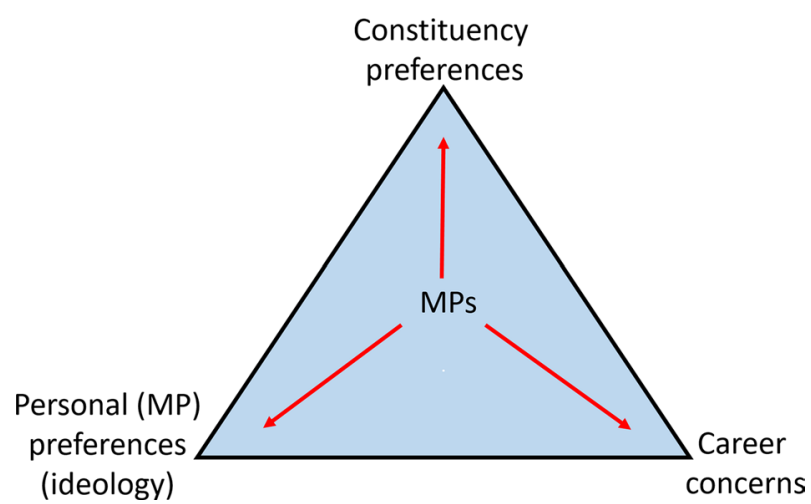

electorally for it. For opposition MPs, the incentive to break the party line to signal "ideological purity" is weaker. Assuming that the opposition party will vote against the government's policy, neither extreme nor moderate (who are relatively close to the center) opposition MPs are likely to gain electorally by breaking the party line because most of their voters would, in fact, prefer the opposition party's official policy stance to that of the government. All rebels, of course, face the cost of the disciplinary actions taken by their party leaders in response, but the benefit of rebellion between the party of government and the opposition clearly is asymmetric. That logic is consistent with the fact that it is MPs with extreme views that tend to rebel in the House of Commons and that MPs from the governing party are more likely to rebel than MPs from the opposition (e.g., Benedetto and Hix 2007; Kirkland and Slapin 2018).

Second, the within-party difference between front- and backbenchers is important and arises from the fact that frontbenchers have much more to lose from rebelling (their perks and posts, the ability to formulate policy and so on). Backbenchers also have to mind their political careers, but those who have been "passed over" for political promotion or those who have been demoted from the frontbench previously have less to lose (Kam 2009). That logic suggests that it is amongst "old" backbenchers that most rebels can be found. The cause of a backbench revolt by that group of MPs may not just be that they are unhappy with the party's policy, but also may be because they hope to destabilize the leader under whom their political careers have stalled. Such considerations give rise to two distinct career motives. On the one hand, MPs can promote their careers by pleasing the current leadership of their party if the leadership is sufficiently stable to justify the expectation of future rewards for good behaviour. On the other hand, MPs can promote their careers by destabilising the current leader of their party and encouraging a leadership challenge. If successful, the revolting MPs reasonably may expect to be rewarded by the new leader.

\section{The data and operationalization}

Our objective is to study how MPs resolved the tension among their personal ideological views, career concerns and constituency preferences in the context of the three Meaningful Votes on May's deal. The raw numbers (reported in Table 1) clearly show that party cohesion was strong among all opposition parties. All but six opposition MPs in the first 
Meaningful Vote and nine in the third toed their respective party lines. ${ }^{10}$ An implication, then, is that the rebellion that defeated May's deal three times in a row took place within the governing Conservative Party. ${ }^{11}$ Our focus is, therefore, on the 317 Conservative MPs. We have recorded how each of them voted in the three Meaningful Votes and coded the indicator variable VOTE as one if the (Conservative) MP supported the Withdrawal Agreement, voting with the government, and zero if the MP rebelled by voting against.

While, theoretically, the three factors of the tripartite model-ideology, career concerns and constituency preferences-are distinct, in practice they often overlap and it is a challenge to measure them independently. With that caveat in mind, we now explain how we operationalize and measure those factors. First, we operationalize the MPs' ideological positions on the Brexit question by how they voted and campaigned in the 2016 referendum on leaving the European Union. For Conservative MPs, the referendum, arguably, was a "free vote" on which the MPs could vote and campaign as they liked. The official policy of the Cameron government that had called the referendum was to vote Remain, but many leading Tory MPs - most notably Boris Johnson and Michael Gove-campaigned to leave. We code the dummy variable REMAIN MP as one if the MP voted and campaigned for remain in the referendum and zero otherwise. We argue that such an expressed preference is a good measure of each MP's personal judgment of the merits of leaving the EU. ${ }^{12}$ However, we acknowledge that how the MPs voted in the referendum can, in principle, also reflect career concerns and constituency preferences. In our judgment, it is unlikely that many Conservative MPs viewed their position on the referendum question as a career move. It was widely expected that the Remain side would win and the Cameron government was unlikely to reward or punish MPs for the stance they took, as Cameron had called the referendum, at least partly, to settle the "Europe question" within the Conservative Party once and for all. It is harder to dismiss the possibility that a significant number of MPs (who did not have strong views on the issue of Europe) chose their positions to match the (perceived) preferences of their constituents. If that were the case, we would expect to find a strong correlation between an MP's position and that of his or her constituents. In fact, the correlation between the leave stance of the MPs and the Leave vote share of their constituents is just 0.129. That correlation does, of course, not rule out that the dummy variable REMAIN MP captures a mixture of personal and constituency preferences. To bolster our interpretation of the variable, we exploit in a robustness check that Theresa May called a general election in 2017 and that we can make a distinction between (current) MPs who were elected before (in 2015) and after (in 2017) the referendum. It is reasonable to expect that constituency preferences played little role in the stances taken by the "MPs" who did not get elected until after the referendum; for them, the expressed preference in the referendum is a reflection of their personal views. We also stress that we condition on a

\footnotetext{
${ }^{10}$ Dewan and Spirling (2011) develop a game theoretical argument for why opposition parties are able to act coherently in spite of the temptation of some of their MPs to support the government's policy. The source of such strategic opposition is that if the opposition as a block vote against the government (and no opposition MP deviates from that), it can force the government to propose a more moderate policy than otherwise and that outcome is in the interest of all opposition MPs.

11 The "rebellion" by the 10 MPs from the Democratic Unionist Party (DUP) which May's government relied on for a parliamentary majority also was important but not pivotal.

12 Moreover, it is plausible to argue that most of them were voting socio-tropically, i.e., were thinking about what, in their view, was best for the country, rather than ego-tropically, i.e., were thinking about the private benefit that they would derive from the result. See Nannestad and Paldam (1994) and Lewis-Beck and Stegmaier (2013) for a discussion of the distinction between ego- and socio-tropic voting.
} 
host of constituency characteristics and on the share of leave voters in the estimations. That strategy helps isolate the variation in REMAIN MP that represents the MPs' personal preferences from the variation that may relate to constituency preferences.

Second, to operationalize career concerns, we make a distinction between "junior" and "senior" backbenchers, on the one hand, and between backbenchers and members of the government (frontbenchers) on the other. As discussed above, the group of "senior" backbenchers, i.e., those with long parliamentary tenures, consists of two sub-groups: one group has been "passed over" for government jobs previously and have little prospect of ever getting one under the current Prime Minister; the other consists of MPs who previously have served in government but have resigned or been dismissed. Either group has little to lose from rebellion because what the government and its Whips can do to sanction them for such behavior is limited since they have little chance of promotion under the current leadership. They are, therefore, ceteris paribus more likely to rebel than "junior" MPs who are newly elected to their seats and who are particularly concerned with their political career prospects under the current leadership. On top of that, if the power base of the current leadership inside the party is fragile, then MPs may anticipate that if they rebel, the current leadership eventually will fall and a new Prime Minster will be appointed. Likely, the new leader will replace many of the old frontbenchers and promote MPs from the backbench. Consequently, MPs who think they have a fair chance of being part of a new government have an extra incentive to rebel. However, that strategy, arguably, is more appealing to "senior" than to "junior" backbenchers who hope to get back into government. So, "junior" MPs have two reasons to toe the party line: they fear sanctions from the current government and they do not anticipate rewards from a new government should the current government fall because of rebellion. We code two variables to capture those calculations. The first, FRONTBENCH, is a dummy variable coded one if the MP holds a position in government and zero otherwise. The second, JUNIOR MP, is a dummy variable coded one if the MP was first elected in either in 2015 or 2017 , and zero otherwise. ${ }^{13}$ The fact that we observe the same MPs voting on the same policy three times and we observe a change in Prime Minister (from Theresa May to Boris Johnson) open a window of opportunity for a more refined test of career concerns related to destabilizing the current leader. We return to that issue in Sect. 7.2.

Third, the Brexit situation provides a unique opportunity for measuring the constituency preferences since we know, in the aggregate, how voters in each constituency voted in the 2016 referendum. ${ }^{14}$ We code the variable LEAVE VOTE SHARE as the fraction of voters in each constituency who voted Leave in the referendum.

We also have collected information on many other MP and constituency specific characteristics. The constituency specific control variables include population size, the unemployment rate, the share of foreign-born residents, the share of residents with higher education, the age structure of the constituency, and share of public employment, all measured at the parliamentary constituency level. The MP specific control variables include the MP's age, gender and win margin in the 2017 election. We also enter a rebellion index that proxies for

\footnotetext{
13 The most recent previous election was in 2010, so by the time of the Meaningful Votes in 2019 an MP with $J U N I O R M P=0$ had served as an MP for at least eight years, long enough to be considered for a government position.

14 Given that actual numbers often are not reported at the parliamentary constituency level, we follow the political science literature (see e.g. Heath and Goodwin 2017) and use estimates constructed by Hanretty (2017).
} 
Table 2 Summary statistics for sample of Conservative backbench MPs

\begin{tabular}{llllll}
\hline Variable & $(1)$ & $(2)$ & $(3)$ & $(4)$ & $(5)$ \\
& $\mathrm{N}$ & Mean & SD & Min. & Max. \\
\hline VOTE (Binary) & 662 & 0.648 & 0.478 & 0 & 1 \\
VOTE CHANGE 1-2* (Binary) & 118 & 0.331 & 0.472 & 0 & 1 \\
VOTE CHANGE 2-3* (Binary) & 118 & 0.356 & 0.481 & 0 & 1 \\
Main determinants & & & & & \\
REMAIN MP (Binary) & 222 & 0.464 & 0.500 & 0 & 1 \\
JUNIOR MP (Binary) & 222 & 0.365 & 0.482 & 0 & 1 \\
LEAVE VOTE SHARE (\%) & 222 & 55.1 & 8.79 & 25.7 & 75.0 \\
JOHNSON GOVERNMENT SENIOR* (Binary) & 118 & 0.068 & 0.252 & 0 & 1 \\
JOHNSON GOVERNMENT JUNIOR* (Binary) & 118 & 0.076 & 0.267 & 0 & 1 \\
Constituency controls & & & & & \\
FOREIGN (\%) & 222 & 8.56 & 6.51 & 2.40 & 46.9 \\
POPULATION (No.) & 222 & 99,558 & 11,238 & 58,873 & 140,264 \\
UNEMPLOYED (\%) & 222 & 1.59 & 0.795 & 0.503 & 4.81 \\
PUBLIC (\%) & 222 & 18.1 & 6.75 & 5.60 & 47.1 \\
EDUCATED (\%) & 222 & 27.2 & 6.94 & 12.3 & 55.2 \\
WORKING AGE (\%) & 222 & 60.7 & 2.86 & 51.4 & 70.3 \\
MP controls & & & & & \\
AGE (years) & 222 & 52.3 & 10.8 & 27.0 & 78.0 \\
FEMALE (Binary) & 222 & 0.176 & 0.381 & 0 & 1 \\
REBELLION (Index) & 222 & 0.723 & 1.87 & 0 & 21.8 \\
WIN MARGIN (pp) & 222 & 22.6 & 12.8 & 0.066 & 49.7 \\
\hline Appentx A & & & & & \\
\hline
\end{tabular}

Appendix A lists the definitions of the variables and provides details regarding the sources. Appendix Table 10 provides summary statistics for the sample of all Conservative MPs. $*$ These variables are coded for the sub-sample of Conservative backbench MPs who voted against the Withdrawal Agreement in the first Meaningful Vote. See Sect. 7.2 for more details

the MP's tendency to rebel against his or her own party in the past. We have standardized these data so that all non-binary variables have a standard deviation of one. Appendix A lists and defines all of the variables we use in the statistical analysis and provides details on their sources. Table 2 reports summary statistics. The data and the Stata code to replicate the results are deposited along with the paper.

\section{Estimation strategy}

We want to estimate the following statistical model:

$$
\operatorname{vOTE}_{i, v}=F\left[\alpha_{v}+\beta_{1} \text { IDEOLOGY }_{i}+\beta_{2} \text { CAREER }_{i}+\beta_{3} \text { CONSTITUENCY }_{i}+\beta_{4} X_{i}\right]
$$

where $i$ is the index for a Conservative MP (and for his or her constituency since all constituencies are single seat), $v$ is the index for the three Meaningful Votes with $v \in\{1,2,3\}$ and $X_{i}$ is a vector of control variables. We want to understand how the three forces-ideology, career concerns and constituency preferences-influence the decision to rebel by voting 
against May's deal. We use REMAIN MP to proxy for ideology, LEAVE VOTE SHARE to proxy for constituency preferences and JUNIOR MP and FRONTBENCH to proxy for career concerns in the main specifications, but consider a number of refinements aimed at validating those three proxies. We estimate Eq. (1) with a probit estimator and, in specifications when we pool the three votes, we cluster the standard errors at the constituency level to account for the fact that we study a sequence of votes.

We know from Table 1 that all Conservative frontbench MPs supported the government's Withdrawal Agreement in the three Meaningful Votes. This implies that we cannot include FRONTBENCH in the probit specification (the variable predicts the outcome perfectly and is dropped). For that reason, the main analysis is restricted to the sample of Conservative backbenchers where we observe variation in VOTE. To compare the effect of the FRONTBENCH variable to the others, we estimate a linear probability model on the sample of all Conservative MPs. We also know from Table 1 that 81 Conservative (backbench) MPs changed their votes from opposition to support in the sequence of votes. To study why they did so, we estimate a version of Eq. (1) where we replace VOTE with either VOTE CHANGE 1-2 or VOTE CHANGE 2-3. Those variables record whether the MPs changed their votes in the second or third Meaningful Vote relative to the position they took in the previous vote, respectively.

\section{Results}

We present the results in three subsections. In Sect. 7.1, we discuss the main results and a validation test of the proxy for the MPs' personal preferences. In Sect. 7.2, we test for career concerns related to promotion to government posts in a future administration. In Sect. 7.3, we investigate heterogeneity in the effects across three dimensions related to electoral competition, history of rebellion, and the MP's personal preferences.

\subsection{Main results}

Table 3 reports the main results. Column (1) shows a parsimonious specification without any control variables other than the dummy variables for the three Meaningful Votes, column (2) adds the constituency specific control variables, and column (3) adds MP-specific control variables. We report marginal effects evaluated at the means of the variables. In column (4), we report the results from a linear probability model estimated with Ordinary Least Squares (OLS) wherein we can include all Conservative MPs, including those serving on the frontbench in the sample.

Looking across Table 3, we observe that the four variables capturing personal preferences (REMAIN MP), career concerns (JUNIOR MP and FRONTBENCH), and constituency preferences (LEAVE VOTE SHARE) are all strongly correlated with MP support for May's deal. The effects are stable across specifications as we add the control variables, except for LEAVE VOTE SHARE which is very imprecisely estimated in the parsimonious specification in column (1). That is, perhaps, not so surprising because the constituency specific controls include many of the variables-such as the unemployment rate and the share of highly educated residents in the constituency-which we know are correlated with the share of Leave voters (see, e.g., Becker et al. 2017). Specifically, we find that REMAIN MP and the two career concerns variables JUNIOR $M P$ and FRONTBENCH are positively correlated with the probability of voting for 
Table 3 The probability of voting for the Withdrawal Agreement in the three Meaningful Votes combined

\begin{tabular}{lllll}
\hline Outcome: VOTE & \multicolumn{2}{l}{ Backbencher sample } & Full sample \\
\cline { 2 - 5 } & $(1)$ & $(2)$ & $(3)$ & $(4)$ \\
& Probit & Probit & Probit & OLS \\
\hline FRONTBENCH & - & - & $0.329^{* * *}$ \\
& & & & $(0.035)$ \\
REMAIN MP & & & & {$[0.000]$} \\
& $0.379^{* * *}$ & $0.369^{* * *}$ & $0.393^{* * *}$ & $0.264^{* * *}$ \\
& $(0.048)$ & $(0.049)$ & $(0.048)$ & $(0.034)$ \\
JUNIOR MP & {$[0.000]$} & {$[0.000]$} & {$[0.000]$} & {$[0.000]$} \\
& $0.179^{* * *}$ & $0.145^{* *}$ & $0.223^{* * *}$ & $0.146^{* * *}$ \\
LEAVE VOTE SHARE & $(0.053)$ & $(0.058)$ & $(0.069)$ & $(0.047)$ \\
& {$[0.001]$} & {$[0.012]$} & {$[0.001]$} & {$[0.002]$} \\
& -0.002 & $-0.156^{* *}$ & $-0.151^{* *}$ & $-0.069^{*}$ \\
Vote dummies & $(0.029)$ & $(0.066)$ & $(0.073)$ & $(0.036)$ \\
Const. controls & {$[0.949]$} & {$[0.017]$} & {$[0.038]$} & {$[0.063]$} \\
MP controls & Yes & Yes & Yes & Yes \\
N & No & Yes & Yes & Yes \\
(Pseudo-)R2 & No & No & Yes & Yes \\
\hline
\end{tabular}

Columns (1)-(3) report Probit estimates (marginal effects evaluated at the mean of the explanatory variables) for the sample of Conservative backbenchers and column (4) reports OLS estimates for the sample of all Conservative MPs. The dependent variable (VOTE) is a binary variable equal to one whenever an MP voted in support of the Withdrawal Agreement and zero when the MP rebelled by voting against. REMAIN $M P$ is a binary variable equal to one if the MP voted for remaining within the EU in the 2016 referendum; JUNIOR MP is a binary variable equal to one if the MP was elected to the House of Commons either in 2015 or 2017; LEAVE VOTE SHARE is the standardized share of voters who voted Leave in the referendum in 2016 in each constituency; and FRONTBENCH is a binary variable equal to one if the MP holds a position in government. All specifications include vote dummies. Constituency controls include population size, the unemployment rate, the share of constituents working in the public sector, the share of constituents with a higher education degree, and the share of constituents who are of working age. MP controls include gender, age, an index of the MP's history of rebellion, and the MP's win margin in the last election. Standard errors (in round brackets) are clustered at the constituency level; $p$-values are given in [square brackets]; ${ }^{*} p<0.10,{ }^{* *} p<0.05,{ }^{* * *} p<0.01$

May's deal and that LEAVE VOTE SHARE is negatively correlated. That is, MPs who had voted and campaigned against leaving the EU in the referendum were almost 40 percentage points more likely to support May's deal than other MPs, while MPs representing constituencies with (one standard deviation) more Leave voters were 15 percentage points less likely to support the deal. Junior MPs mindful of their career prospects under a May government were about 22 percentage points more likely to support her deal and so were frontbench MPs serving in the government [column (4)]. Relatively speaking, ideology (as captured by the MP's revealed preference for membership of the EU) appears to be about twice as important a factor as career concerns and constituency preferences. In sum, we conclude that the rebellion did not come from MPs with strong career concerns. That result is in line with previous findings in the literature on roll call rebels (see, e.g., Benedetto and Hix 2007). Rather, and somewhat paradoxically, 
Table 4 The probability of voting for the Withdrawal Agreement in each of the three Meaningful Votes separately

\begin{tabular}{|c|c|c|c|c|}
\hline \multirow[t]{2}{*}{ Outcome: VOTE } & (1) & (2) & (3) & (4) \\
\hline & 1st Vote & 2nd Vote & 3rd Vote & Diff. $p$-value \\
\hline \multirow[t]{3}{*}{ REMAIN MP } & $0.556^{* * *}$ & $0.399 * * *$ & $0.158 * * *$ & \multirow[t]{3}{*}{0.000} \\
\hline & $(0.061)$ & $(0.059)$ & $(0.044)$ & \\
\hline & {$[0.000]$} & {$[0.000]$} & {$[0.000]$} & \\
\hline \multirow[t]{3}{*}{ JUNIOR MP } & $0.327 * * *$ & $0.209 * *$ & $0.112 * *$ & \multirow[t]{3}{*}{0.031} \\
\hline & $(0.103)$ & $(0.087)$ & $(0.051)$ & \\
\hline & {$[0.002]$} & {$[0.016]$} & {$[0.027]$} & \\
\hline \multirow[t]{3}{*}{ LEAVE VOTE SHARE } & -0.150 & $-0.165^{*}$ & $-0.120^{* *}$ & \multirow[t]{3}{*}{0.414} \\
\hline & $(0.121)$ & $(0.088)$ & $(0.061)$ & \\
\hline & {$[0.217]$} & {$[0.061]$} & {$[0.048]$} & \\
\hline Controls & Yes & Yes & Yes & - \\
\hline $\mathrm{N}$ & 221 & 220 & 221 & - \\
\hline Pseudo- $\mathrm{R}^{2}$ & 0.31 & 0.22 & 0.17 & - \\
\hline
\end{tabular}

The table reports Probit estimates (marginal effects evaluated at the mean of the explanatory variables) for the sample of Conservative backbenchers separately for the three Meaningful Votes. The dependent variable (VOTE) is a binary variable equal to one whenever an MP voted in support of the Withdrawal Agreement and zero if the MP rebelled by voting against. REMAIN MP is a binary variable equal to one if the MP voted for remaining within the EU in the 2016 referendum; JUNIOR MP is a binary variable equal to one if the MP was elected to the House of Commons either in 2015 or 2017; and LEAVE VOTE SHARE is the standardized share of voters who voted Leave in the referendum in 2016 in each constituency. All specifications include vote dummies. Constituency controls include population size, the unemployment rate, the share of constituents working in the public sector, the share of constituents with a higher education degree, and the share of constituents who are of working age. MP controls include gender, age, an index of the MP's history of rebellion, and the MP's win margin in the last election. The $p$-value reported in column (4) is associated with the one-sided null hypothesis that the marginal effect of the respective row variable is numerically smaller in the third vote [column (3)] than in the first vote [column (1)]. Robust standard errors (in round brackets); $p$-values are given in [square brackets]; $* p<0.10, * * p<0.05, * * * p<0.01$

rebellion came from MPs who had supported Leave in the referendum and from MPs elected in Leave leaning constituencies.

Table 4 reports the results (corresponding to the specification with the full set of control variables in Table 3, column (3) for each of the three Meaningful Votes separately. That evidence is important to consider because a significant shift in the scale of the rebellion materialized from 118 Conservative MPs, dropping in the first Meaningful Vote down to 37 in the third. The results are qualitatively similar across the three votes: the marginal effects have the same signs and are, with one exception, statistically significant. Importantly, the tests for whether the marginal effects are the same in the first and third vote reported in column (4), however, show the quantitative importances of ideology and career concerns, but not constituency preferences, weakened over time, in line with the fact that more and more backbenchers rallied behind May's deal as time went on. ${ }^{15}$ To illustrate,

15 It is not straight-forward to compare coefficients in a non-linear model. We follow Mood (2010) and use a one-sided z-test to calculate, for each variable, if one marginal effect (rather than the raw probit coefficients) is large (smaller) than the other. We use the same procedure in the heterogeneity analysis in Sect. 7.3. 
Table 5 The probability of voting for the Withdrawal Agreement for the Conservative backbench MPs not serving in 2016

\begin{tabular}{|c|c|c|c|}
\hline Outcome: VOTE & $\begin{array}{l}(1) \\
\text { Probit }\end{array}$ & $\begin{array}{l}\text { (2) } \\
\text { Probit }\end{array}$ & $\begin{array}{l}\text { (3) } \\
\text { Probit }\end{array}$ \\
\hline REMAIN MP & $\begin{array}{l}0.295 * * * \\
(0.103) \\
{[0.004]}\end{array}$ & $\begin{array}{l}0.286 * * * \\
(0.093) \\
{[0.002]}\end{array}$ & $\begin{array}{l}0.295 * * * \\
(0.105) \\
{[0.005]}\end{array}$ \\
\hline LEAVE VOTE SHARE & $\begin{array}{l}-0.066^{*} \\
(0.037) \\
{[0.076]}\end{array}$ & $\begin{array}{l}-0.148^{* * *} \\
(0.065) \\
{[0.023]}\end{array}$ & $\begin{array}{l}-0.084 \\
(0.082) \\
{[0.303]}\end{array}$ \\
\hline Vote dummies & Yes & Yes & Yes \\
\hline Const. controls & No & Yes & Yes \\
\hline MP controls & No & No & Yes \\
\hline $\mathrm{N}$ & 104 & 104 & 104 \\
\hline Pseudo- $\mathrm{R}^{2}$ & 0.27 & 0.33 & 0.38 \\
\hline
\end{tabular}

The table reports Probit estimates (marginal effects evaluated at the mean of the explanatory variables) for the sample of Conservative backbenchers who did not serve as representatives at the time of the 2016 EU Membership Referendum. Due to limited variation, the variable JUNIOR MP is omitted. The other variables are as in the specifications reported in Table 3, columns (1) to (3). Standard errors (in round brackets) are clustered at the constituency level; $p$-values are given in [square brackets]; ${ }^{*} p<0.10,{ }^{* *} p<0.05,{ }^{* * *} p<0.01$

relative to the first Meaningful Vote, wherein the MPs who had voted Remain in 2016 were 56 percentage points more likely to support May's deal, the marginal effect dropped down to 16 percentage points by the time of the third Meaningful Vote. We also note that the fraction of the variance explained by the three factors (as measured by the Pseudo- $R^{2}$ ) drops from 31 to $17 \%$.

As discussed above, we cannot fully rule out that the estimated marginal effect of REMAIN MP, which records the stance of each MP in the 2016 referendum, captures constituency as well as the MP's personal preferences. The fact that we condition on the LEAVE VOTE SHARE and, thus, estimate the effect of REMAIN MP holding the preferences of the voters in each constituency for leaving the European Union constant militates against that interpretation. Yet, it is important to consider the issue further.

The MPs who voted on the Withdrawal Agreement in the three Meaningful Votes can be divided between those who also were part of the 2015 Parliament and, therefore, were serving as representatives at the time of the referendum, and those who were not members of the past legislative (i.e., those entering the House of Commons in 2017). If the MPs' stances in the referendum were selected strategically to match constituency preferences, we conjecture that the incentive to do so would be much stronger for those who already were MPs at the time of the referendum. After all the MPs elected in 2017 did not know in 2016 that they would be running in a general election shortly after the referendum vote and, thus, their incentive to match their stances with those of future voters arguable is much weaker. For them, it stands to reason that the referendum vote does reflect their personal preference.

Given that consideration, we can isolate the effect of the MPs' personal preferences by restricting the sample to the Conservative backbench MPs who did not serve in parliament at the time of the 2016 referendum and test if those who voted Remain are more likely than those who did not to vote for the Withdrawal Agreement. Table 5 reports three specifications with different sets of control variables similar to Table 3. We see that REMAIN 
$M P$ is statistically significant in all specifications, and that the marginal effect is about 30 percentage points compared to 40 percentage points in the full sample (see Table 3). The result bolsters our interpretation of REMAIN MP as a plausible proxy for the MPs' personal preferences.

\subsection{Career concerns and leader replacement}

So far we have assumed that the MPs' career concerns are shaped by the ability of the current party leadership to reward loyalty and punish rebellion. However, the prospect of a career under a new party leader also can be a strong motivator for rebelling against the current leadership, particularly so if its position is perceived to be weak and rebellion is a means to weaken it further. In the context of the three Meaningful Votes, it is clear that the position of the May government was fragile. This, combined with the fact that she eventually was replaced by Boris Johnson as Prime Minster, opens up a unique opportunity to test if the backbenchers' vote choices in the Meaningful Votes were influenced by the prospect of a promotion under a future Johnson-led government. To do that, we note two points. Firstly, since Theresa May had "survived" an internal vote of no confidence before the first meaningful vote, it is reasonable to assume that expectations of a change in leadership were lower at the time of the first vote than at the time of the last. This motivates investigating why some Conservative backbenchers changed their positions on the Withdrawal Agreement between the first, second and third votes. Secondly, Johnson widely was tipped as the most likely candidate to replace May if her administration were to fall. He announced just before the third Meaningful Vote that he would support it after having voted against in the previous votes. ${ }^{16}$ We can use Johnson's PM expectations to test if those MPs who (ex post) got promoted by his new administration were "loyal" to him and also switched their votes when he did. If so, such vote switching would be consistent with the prospect of promotion under a future government being a motivator.

To implement that test, we code the two variables JOHNSON GOVERNMENT SENIOR and JOHNSON GOVERNMENT JUNIOR which are set equal to one if an MP got a senior (Cabinet) or a junior (non-cabinet) post, respectively, in the Johnson administration. We, then, test whether those variables can predict if the 118 Conservative backbench MPs who voted against the Withdrawal Agreement in the first Meaningful Vote changed the way they voted in subsequent votes. Table 6 reports the results. In column (1), the dependent variable (VOTE CHANGE 1-2) is a dummy equal to one for MPs who voted against in the first Meaningful Vote and for in the second (zero otherwise). In column (2), the dependent variable (VOTE CHANGE 2-3) is a dummy equal to one for MPs who voted against in the second Meaningful Vote and for in the third (zero otherwise). While our results should be interpreted cautiously because of the small sample size, ${ }^{17}$ we see that the MPs who were appointed to senior positions in the Johnson administration were 36 percentage points less likely to change their votes between the first and the second vote, but 36 percentage points more likely to switch between the second and the third vote. Those appointed junior

\footnotetext{
16 Since the DUP was sure to vote against for a third time, it would have required a major rebellion in the Labour Party to create a majority for the Withdrawal Agreement, even if most of the rebels on the Conservative backbench switched their votes. So, Johnson's change of mind never was likely to make a material difference in the outcome of the vote.

17 Only about $7 \%$ of the backbenchers who voted initially against the Withdrawal Agreement are now part of the Johnson Cabinet.
} 
Table 6 Voting with Johnson: the probability that the 118 Conservative backbench MPs who voted against the Withdrawal Agreement in the first Meaningful vote subsequently switched their vote

\begin{tabular}{lll}
\hline Outcome: VOTE CHANGE & $(1)$ & $(2)$ \\
& Switch in 2nd vote & Switch in 3rd vote \\
\hline JOHNSON GOVERNMENT SENIOR & $-0.363^{* * *}$ & $0.362^{* *}$ \\
& $(0.105)$ & $(0.161)$ \\
& {$[0.001]$} & {$[0.027]$} \\
JOHNSON GOVERNMENT JUNIOR & 0.113 & 0.070 \\
& $(0.188)$ & $(0.187)$ \\
REMAIN MP & {$[0.550]$} & {$[0.712]$} \\
& 0.092 & -0.028 \\
JUNIOR MP & $(0.111)$ & $(0.108)$ \\
& {$[0.407]$} & {$[0.799]$} \\
& -0.098 & 0.110 \\
LEAVE VOTE SHARE & $(0.153)$ & $(0.150)$ \\
& {$[0.523]$} & {$[0.463]$} \\
Const. controls & -0.010 & -0.141 \\
MP controls & $(0.136)$ & $(0.130)$ \\
N & {$[0.944]$} & {$[0.283]$} \\
$R^{2}$ & Yes & Yes \\
\hline
\end{tabular}

The sample is restricted to Conservative backbencher MPs who voted against the Withdrawal Agreement in the first Meaningful Vote. In column (1), the dependent variable (VOTE CHANGE 1-2) is a dummy equal to one for MPs who voted against in the first Meaningful Vote and for in the second (zero otherwise). In column (2), the dependent variable (VOTE CHANGE 2-3) is a dummy equal to one for MPs who voted against in the second Meaningful Vote and for in the third (zero otherwise). The dummy variable $J O H N$ SON GOVERNMENT SENIOR is equal to one if the MP was appointed to a senior (Cabinet) position in the Johnson administration (zero otherwise). The dummy variable JOHNSON GOVERNMENT JUNIOR is equal to one if the MP was appointed to a junior (non-cabinet) governmental position in the Johnson administration (zero otherwise). The model is a linear probability model estimated with Ordinary Least Squares (OLS). The probit estimates are similar. However, because no MP who got a senior position in the Johnson administration started supporting Theresa May's deal in the 2nd vote, we cannot estimate the specification in column (1) with that estimator. REMAIN MP is a binary variable equal to one if the MP voted for remaining within the EU in the 2016 referendum; JUNIOR MP is a binary variable equal to one if the MP was elected to the House of Commons either in 2015 or 2017; LEAVE VOTE SHARE is the standardized share of voters who voted Leave in the referendum in 2016 in each constituency. Constituency controls include population size, the unemployment rate, the share of constituents working in the public sector, the share of constituents with a higher education degree, and the share of constituents who are of working age. MP controls include gender, age, an index of the MP's history of rebellion, and the MP's win margin in the last election. Robust standard errors are reported in (round brackets); $p$ values are given in [square brackets]; ${ }^{*} p<0.10,{ }^{* *} p<0.05,{ }^{* * *} p<0.01$

positions were not more likely to change their vote than other MPs. That finding is consistent with a "follow Johnson effect" whereby the rebels who anticipated (correctly) that they might get senior posts in a Johnson administration changed their votes when Johnson did. Although other explanations for that pattern are possible, it suggests that career concerns related to rewards by a future leader were salient. 


\subsection{Heterogeneity}

We explore three dimensions of heterogeneity in the main results: constituency competitiveness, history of rebellion, and the MP's personal preferences. ${ }^{18}$

\subsubsection{Constituency competitiveness}

The relative importance of ideology, career concerns and constituency preferences in an MP's rebellion calculus is likely to be influenced by the competitiveness the MP's seat. An MP elected to a safe seat by a large majority is likely to put more weight on career concerns and ideology than on constituency preferences than an MP elected to a marginal seat. To investigate that hypothesis, we split the sample of Conservative backbench MPs into sub-samples defined by their win margins in the 2017 general election and re-estimate Eq. (1) on these sub-samples. We define a seat as marginal if it is in the bottom $25 \%$ of the distribution with win margins below 11 percentage points and safe if it is in the top $50 \%$ of the distribution with a win margin above 23 percentage points.

Table 7 reports the results. Column (1) repeats the baseline model estimated on the entire sample of backbench Conservative MPs. In columns (2) and (3), we report the results for safe and marginal seats separately. We observe a remarkable difference in the relative importance of career concerns and constituency preferences between MPs elected in safe versus marginal seats. Specifically, the effect of career concerns is significantly weaker in marginal constituencies, while the influence of constituency preferences is significantly stronger. The results align with previous findings by Baughman (2004), who associates the greater attention paid to constituency preferences by MPs under electoral threat by pandering to local party officials whose support is essential for future electoral success. Likewise, Kauder and Potrafke (2019) show that conservative politicians elected in safe rather than in contested districts were less likely to support same-sex marriage in a roll call vote in the national German parliament (Bundestag).

While those results should not necessarily be interpreted causally because win margins may be correlated with unobserved mediating factors, we do believe that they bring credibility to our main findings. If the main results from Table 3 were wholly spurious, we would have no reason to expect the particular pattern we observe when the sample is split between safe and marginal seats. Hence, while making a causal claim is not possible with the data at hand, the results in Table 7 are in line with what we would expect theoretically, which is reassuring.

\subsubsection{History of rebellion}

While many MPs are loyal, some MPs are serial rebels and have long histories of voting against their parties. Famous examples include the now leader of the Labour Party Jeremy Corbyn and the shadow Chancellor John McDonnell and, amongst the Conservatives, the MP Philip Hollobone. We conjecture that an MP with a history of rebellion would respond differently to, in particular, career concerns than an MP who

\footnotetext{
18 Methodologically, we study heterogeneity by splitting the sample along the relevant dimension and then test if the marginal effects of the core variables are different in the two sub-samples. An alternative is to introduce interaction terms. However, since we are interested in heterogeneity across many variables, that approach, despite the efficiency gain associated with a larger sample, is inferior for our purposes.
} 
Table 7 The probability of voting for the Withdrawal Agreement in safe versus marginal seats

\begin{tabular}{lllll}
\hline Outcome: VOTE & $(1)$ & $(2)$ & $(3)$ & $(4)$ \\
& Baseline & Safe & Marginal & Diff. p-value \\
\hline REMAIN MP & $0.393^{* * *}$ & $0.493^{* * *}$ & $0.431^{* * *}$ & 0.278 \\
& $(0.048)$ & $(0.076)$ & $(0.085)$ & \\
& {$[0.000]$} & {$[0.000]$} & {$[0.000]$} & \\
JUNIOR MP & $0.223^{* * *}$ & $0.271^{* * *}$ & -0.048 & 0.034 \\
& $(0.069)$ & $(0.105)$ & $(0.139)$ & \\
LEAVE VOTE SHARE & {$[0.001]$} & {$[0.010]$} & {$[0.730]$} & \\
& $-0.151^{* *}$ & -0.055 & $-0.314^{* * *}$ & 0.076 \\
Vote dummies & $(0.073)$ & $(0.154)$ & $(0.095)$ & \\
Controls & {$[0.038]$} & {$[0.722]$} & {$[0.001]$} & \\
$\mathrm{N}$ & Yes & Yes & Yes & - \\
Pseudo- $\mathrm{R}^{2}$ & Yes & Yes & Yes & - \\
\hline
\end{tabular}

The table reports Probit estimates (marginal effects evaluated at the mean of the explanatory variables) for the sample of Conservative backbenchers and for the three votes combined. Column (1) replicates the full baseline results from Table 3. Columns (2) and (3) estimate the model separately for safe (top $50 \%$ of the win margin distribution) and marginal (bottom $25 \%$ of the distribution) seats. The dependent variable (VOTE) is a binary variable equal to one whenever an MP voted in support of the Withdrawal Agreement and zero if the MP rebelled by voting against. REMAIN MP is a binary variable equal to one if the MP voted for remaining within the EU in the 2016 referendum; JUNIOR MP is a binary variable equal to one if the MP was elected to the House of Commons either in 2015 or 2017; and LEAVE VOTE SHARE is the standardized share of voters who voted Leave in the referendum in 2016 in each constituency. All specifications include vote dummies. Constituency controls include population size, the unemployment rate, the share of constituents working in the public sector, the share of constituents with a higher education degree, and the share of constituents who are of working age. MP controls include gender, age, an index of the MP's history of rebellion, and the MP's win margin in the last election. The p-value reported in column (4) is associated with the one-sided null hypothesis that the marginal effect of the respective row variable is larger (smaller) in one sub-sample than in the other. Standard errors (in round brackets) are clustered at the constituency level; $p$ values are given in [square brackets]; ${ }^{*} p<0.10,{ }^{* *} p<0.05,{ }^{* * *} p<0.01$

always has been loyal. An MP who has rebelled at least once may, from a career point of view, perceive another rebellious vote differently from an MP who has been loyal in the past.

Based on the the "rebellion history index" constructed by the website The Public Whip from divisions in the House of Commons over the period from June 2017 to November 2018 (i.e., before the first Meaningful Vote), we have divided the sample of Conservative backbench MPs into two groups: those who never rebelled in the past and for whom a vote against the Withdrawal Agreement would be their first rebellious vote (first-time rebels) and those who rebelled at least once prior to the first Meaningful Vote (serial rebels). We re-estimate Eq. (1) on the two sub-samples. Table 8 reports the results. From columns (2) and (3), we observe that based on a comparison of the marginal effects (28 versus 19 percentage points), career concerns do appear to matter more for first-time than for serial rebels, but the difference is not statistically significant. An MP's history of rebellion, thus, did not make much of a difference for how they voted on Brexit. 
Table 8 The probability of voting for the Withdrawal Agreement, breakdown by history of past rebellion

\begin{tabular}{|c|c|c|c|c|}
\hline \multirow[t]{2}{*}{ Outcome: VOTE } & (1) & (2) & (3) & (4) \\
\hline & Baseline & First-time rebels & Serial rebels & Diff. $p$-value \\
\hline \multirow[t]{3}{*}{ REMAIN MP } & $0.371 * * *$ & $0.397 * * *$ & $0.399 * * *$ & \multirow[t]{3}{*}{0.491} \\
\hline & $(0.049)$ & $(0.064)$ & $(0.074)$ & \\
\hline & {$[0.000]$} & {$[0.000]$} & {$[0.000]$} & \\
\hline \multirow[t]{3}{*}{ JUNIOR MP } & $0.227 * * *$ & $0.280 * * *$ & $0.189 * *$ & \multirow[t]{3}{*}{0.257} \\
\hline & $(0.068)$ & $(0.101)$ & $(0.096)$ & \\
\hline & {$[0.001]$} & {$[0.006]$} & {$[0.048]$} & \\
\hline \multirow[t]{3}{*}{ LEAVE VOTE SHARE } & $-0.154 * *$ & -0.115 & $-0.197^{*}$ & \multirow[t]{3}{*}{0.298} \\
\hline & $(0.072)$ & $(0.116)$ & $(0.101)$ & \\
\hline & {$[0.034]$} & {$[0.321]$} & {$[0.052]$} & \\
\hline Vote dummies & Yes & Yes & Yes & - \\
\hline Controls & Yes & Yes & Yes & - \\
\hline $\mathrm{N}$ & 662 & 306 & 356 & - \\
\hline Pseudo- $\mathrm{R}^{2}$ & 0.26 & 0.32 & 0.26 & - \\
\hline
\end{tabular}

The table reports Probit estimates (marginal effects evaluated at the mean of the explanatory variables) for the sample of Conservative backbenchers and the three Meaningful Votes combined. Column (1) replicates the full baseline results from Table 3, excluding the rebellion index control. Column (2) restricts the sample to MPs who had not rebelled prior to November 2017 (first-time rebels); column (3) restricts the sample to MPs who had rebelled at least once before (serial rebels). The dependent variable (VOTE) is a binary variable equal to one whenever an MP voted in support of the Withdrawal Agreement and zero if the MP rebelled by voting against. REMAIN MP is a binary variable equal to one if the MP voted for remaining within the EU in the 2016 referendum; JUNIOR MP is a binary variable equal to one if the MP was elected to the House of Commons either in 2015 or 2017; and LEAVE VOTE SHARE is the standardized share of voters who voted Leave in the referendum in 2016 in each constituency. All specifications include vote dummies. Constituency controls include population size, the unemployment rate, the share of constituents working in the public sector, the share of constituents with a higher education degree, and the share of constituents who are of working age. MP controls include gender, age, and the MP's win margin in the last election. The p-value reported in column (4) is associated with the one-sided null hypothesis that the marginal effect of the respective row variable is larger (smaller) in one sub-sample than in the other. Standard errors (in round brackets) are clustered at the constituency level; $p$ values are given in [square brackets]; ${ }^{*} p<0.10,{ }^{* *} p<0.05,{ }^{* * *} p<0.01$

\subsubsection{The MPs' personal Brexit preference}

We already have established that conservative backbench MPs who supported Remain in the 2016 referendum were more likely to support May's deal in the three Meaningful Votes than Leave MPs. We split the sample into Leave and Remain MP sub-samples in order to investigate if the two groups of MPs reacted differently to career concerns and to constituency preferences. Table 9 reports the results. We observe that Remain MPs reacted to career concerns and not to constituency preferences, while for Leave MPs, career concerns appear to play no role, but they were more likely to vote against the deal if elected in constituencies with large fractions of Leave voters. However, despite the fact that the marginal effect on JUNIOR MP is insignificant for Leave MPs and significant for Remain MPs, the difference between the two marginal effects is not statistically significant. For LEAVE VOTE SHARE the difference is significant. One interpretation of that evidence is that Leave MPs, many of whom belong to the European Research Group (ERG) led by Jacob ReesMogg, signalled "ideological purity" to the Leave voters and local party officials in their 
Table 9 The probability of voting for the Withdrawal Agreement for remain and leave MPs

\begin{tabular}{|c|c|c|c|c|}
\hline \multirow[t]{2}{*}{ Outcome: VOTE } & (1) & (2) & (3) & (4) \\
\hline & Baseline & Leave MPs & Remain MPs & Diff. $p$-value \\
\hline \multirow[t]{3}{*}{ JUNIOR MP } & $0.211 * * *$ & 0.135 & $0.231 * * *$ & \multirow[t]{3}{*}{0.233} \\
\hline & $(0.069)$ & $(0.118)$ & $(0.060)$ & \\
\hline & {$[0.002]$} & {$[0.254]$} & {$[0.000]$} & \\
\hline \multirow[t]{3}{*}{ LEAVE VOTE SHARE } & $-0.155 * *$ & $-0.253 * *$ & 0.008 & \multirow[t]{3}{*}{0.013} \\
\hline & $(0.069)$ & $(0.100)$ & $(0.061)$ & \\
\hline & {$[0.026]$} & {$[0.011]$} & {$[0.893]$} & \\
\hline Vote dummies & Yes & Yes & Yes & - \\
\hline Controls & Yes & Yes & Yes & - \\
\hline $\mathrm{N}$ & 662 & 354 & 308 & - \\
\hline Pseudo- $R^{2}$ & 0.15 & 0.21 & 0.27 & - \\
\hline
\end{tabular}

The table reports Probit estimates (marginal effects evaluated at the mean of the explanatory variables) for the sample of Conservative backbenchers for the three Meaningful Votes combined. Column (1) replicates the baseline result from Table 3, excluding REMAIN MP. Column (2) restricts the sample to MPs who voted Leave in the 2016 referendum (Leave MPs). Column (3) restricts the sample to MPs who voted Remain in the referendum (Remain MPs). The dependent variable (VOTE) is a binary variable equal to one whenever an MP voted in support of the Withdrawal Agreement and zero if the MP rebelled. REMAIN MP is a binary variable equal to one if the MP voted for remaining within the $\mathrm{EU}$ in the 2016 referendum; JUNIOR MP is a binary variable equal to one if the MP was elected to the House of Commons either in 2015 or 2017; and LEAVE VOTE SHARE is the standardized share of voters who voted Leave in the referendum in 2016 in each constituency. All specifications include vote dummies. Constituency controls include population size, the unemployment rate, the share of constituents working in the public sector, the share of constituents with a higher education degree, and the share of constituents who are of working age. MP controls include gender, age, an index of the MP's history of rebellion, and the MP's win margin in the last election. The p-value reported in column (4) is associated with the one-sided null hypothesis that the marginal effect of the respective row variable is larger (smaller) in one sub-sample than in the other. Standard errors (in round brackets) are clustered at the constituency level; $p$-values are given in [square brackets]; ${ }^{*} p<0.10$, ${ }^{* *} p<0.05,{ }^{* * *} p<0.01$

constituencies by voting against May's deal which they considered to be too "soft" (involving a risk of locking the UK into a customs union through the so-called Irish backstop). Remain MPs with political careers to look after, on the other hand, could signal purity to their Leave voters and local party officials by "converting" (accepting the result of the referendum) and supporting May's attempt to get a deal through.

\subsection{Johnson's October 2019 Brexit deal}

As discussed in Sect. 3, Prime Minister Johnson put a new Brexit deal before Parliament which passed its second reading on 22 October 2019 with a majority of 30. It got no further because a general election was called. As explained, passing a second reading is not equivalent to passing one of the Meaningful Votes considered above, but some interesting patterns nevertheless should be noted. The $30 \mathrm{MP}$ majority was achieved largely thanks to 24 Labour MPs defying their party and either voting for Johnson's deal (19) or abstaining (5). By comparing descriptive statistics, these rebel Labour MPs appear to be guided by motivations similar to those of the Conservative rebels analyzed above. Rebel Labour MPs had substantially higher constituency Leave vote shares than loyal Labour MPs (62.2\% vs. $50.1 \%$ ), they were less likely to have campaigned for Remain (87.5\% vs. 98.2\%), and less 
likely to be junior (33.3\% vs. $42.4 \%$ ). Hence, we see patterns of rebellion by Labour MPs consistent with our findings for Conservative MPs.

\section{Conclusions}

We study the three Meaningful Votes that took place in the British House of Common between January and March 2019 in which the Conservative government's Withdrawal Agreement with the European Union was defeated decisively. Instrumental for that result was a major revolt on the Conservative backbench. We argue that this high-stakes situation can provide insights into why politicians revolt against their own parties more generally. We find evidence that personal preferences (ideology), constituency preferences and career concerns mattered. We also find (suggestive) evidence that the rebellion on the Conservative backbench was, in part, motivated by the prospect of bringing the May government down. An interesting question for future research is to study the electoral consequences of the rebellion for individual MPs. That is, do voters reward or punish them for the ways they voted on the highly contentious Brexit issue? A related question that also deserves attention is how the Conservative Party internally rewards or punishes rebellious MPs, i.e., how will the rebellion affect their long-term career prospects?

Acknowledgements We would like to thank Niklas Potrafke, Colin Jennings, Thomas Stratmann, PierreGuillaume Méon and the participants in the 2019 Silvaplana workshop in political economy for constructive comments. We are also grateful for the helpful advice from the reviewers and the editor.

Open Access This article is licensed under a Creative Commons Attribution 4.0 International License, which permits use, sharing, adaptation, distribution and reproduction in any medium or format, as long as you give appropriate credit to the original author(s) and the source, provide a link to the Creative Commons licence, and indicate if changes were made. The images or other third party material in this article are included in the article's Creative Commons licence, unless indicated otherwise in a credit line to the material. If material is not included in the article's Creative Commons licence and your intended use is not permitted by statutory regulation or exceeds the permitted use, you will need to obtain permission directly from the copyright holder. To view a copy of this licence, visit http://creativecommons.org/licenses/by/4.0/.

\section{Appendix A: definitions and sources}

This Appendix lists and defines the variables we use in the statistical analysis and gives the sources.

- VOTE is a dummy variable coded one if an MP voted for the government's deal and zero if they voted against; coded separately for each of the three votes. This coding takes into account that the Tellers, the Speaker and the deputy Speaker do not cast a vote. Note: Data retrieved April 2019. Source: House of Commons Votes

- VOTE CHANGE 1-2 (VOTE CHANGE 2-3) is a dummy equal to one for MPs who voted against in the first (second) Meaningful Vote and for in the second (third) (zero otherwise). Note: Data retrieved April 2019. Source: House of Commons Votes

- REMAIN MP is a dummy variable coded one if the MP voted and campaigned to remain in the referendum and zero otherwise. Note: Data retrieved November 2018. Source: SkyNews Analysis 
- FRONTBENCH is a dummy variable coded one if the MP holds a governmental position and zero otherwise. Note: Data retrieved November 2018. Source: House of Commons Library

- JUNIOR MP is a dummy variable coded one if the MP first entered Parliament either in 2015 or 2017 and zero otherwise. Note: Data retrieved November 2018. Source: House of Commons Library

- LEAVE VOTE SHARE records the (estimated) share of the electorate in each constituency who voted to leave the EU in the 2016 referendum. Note: Data retrieved November 2018. Source: Hanretty, 2017

- FOREIGN records the share of people residing within a constituency that have not been born within the UK. Data for March 2015. Note: Data retrieved November 2018. Source: Office for National Statistics

- PUBLIC records the share of people residing within a constituency employed in the public sector. Data for March 2015. Note: Data retrieved November 2018. Source: Offic e for National Statistics

- EDUCATED records the March share of people residing within a constituency that have a degree of higher education. Data for March 2015. Note: Data retrieved November 2018. Source: Office for National Statistics

- POPULATION records the number of people residing within a constituency. Data for June 2016. Note: Data retrieved November 2018. Source: House of Commons Library Local Data

- WORKING AGE records the share of people residing within a constituency that are between 16 and 64 years old. Data for June 2016. Note: Data retrieved November 2018. Source: House of Commons Library Local Data

- UNEMPLOYED records the unemployment rate within a constituency. Data for June 2016. Note: Data retrieved November 2018. Source: House of Commons Library Local Data

- AGE records the representative's age in years. Note: Data retrieved November 2018. Source: House of Commons Library

- FEMALE is a dummy variable coded one if the MP is female. Note: Data retrieved November 2018. Source: House of Commons Library

- REBELLION is an index variable which proxies for the number of times a representative has voted against the majority vote of the representative's party. Note: Data retrieved November 2018. Source: The Public Whip

- WIN MARGIN records, for each constituency, the difference between the vote share of the winning candidate and the vote share of the runner up. Note: Data retrieved November 2018. Source: House of Commons Library

- JOHNSON GOVERNMENT SENIOR is equal to one if the MP was appointed to a senior (Cabinet) position in the Johnson administration (zero otherwise). Note: Data retrieved July 31 2019. Source: BBC News

- JOHNSON GOVERNMENT JUNIOR is equal to one if the MP was appointed to a junior (non-cabinet) governmental position in the Johnson administration (zero otherwise). Note: Data retrieved July 31 2019. Source: BBC News 


\section{Appendix B: additional data and estimation results}

See Tables 10, 11, 12, 13 and 14.

Table 10 Summary statistics for sample of all Conservative MPs

\begin{tabular}{llllll}
\hline Variable & $(1)$ & $(2)$ & $(3)$ & $(4)$ & $(5)$ \\
& $\mathrm{N}$ & Mean & SD & Min. & Max. \\
\hline VOTE (Binary) & 941 & 0.752 & 0.432 & 0 & 1 \\
Main determinants & & & & & \\
FRONTBENCH (Binary) & 317 & 0.300 & 0.459 & 0 & 1 \\
REMAIN MP (Binary) & 317 & 0.546 & 0.499 & 0 & 1 \\
JUNIOR MP (Binary) & 317 & 0.300 & 0.459 & 0 & 1 \\
LEAVE VOTE SHARE (\%) & 317 & 55.0 & 8.77 & 25.7 & 75.0 \\
Constituency controls & & & & & \\
FOREIGN (\%) & 317 & 8.86 & 6.94 & 2.30 & 52.0 \\
POPULATION (No.) & 317 & 100,324 & 11,371 & 58,873 & 140,264 \\
UNEMPLOYED (\%) & 317 & 1.53 & 0.770 & 0.393 & 4.81 \\
PUBLIC (\%) & 317 & 17.8 & 6.56 & 5.60 & 47.1 \\
EDUCATED (\%) & 317 & 27.6 & 7.14 & 12.3 & 55.2 \\
WORKING AGE (\%) & 317 & 60.8 & 2.79 & 51.4 & 73.6 \\
MP controls & & & & & \\
AGE (years) & 317 & 51.6 & 9.85 & 27.0 & 78.0 \\
FEMALE (Binary) & 317 & 0.211 & 0.409 & 0 & 1 \\
REBELLION (Index) & 317 & 0.636 & 1.59 & 0 & 21.8 \\
WIN MARGIN (pp) & 317 & 23.2 & 13.1 & 0.066 & 49.7 \\
\hline
\end{tabular}

Appendix A lists definitions of the variables and provides details regarding the sources. The sample is used to estimate the specification in Table 3, column (4) 
Table 11 The probability of voting for the Withdrawal Agreement in the three Meaningful Votes combined, Linear Probability Model

\begin{tabular}{lllllll}
\hline & \multicolumn{5}{l}{ A. All Conservatives } & \multicolumn{3}{l}{ B. Conservative Backbenchers } \\
\hline FRONTBENCH & $0.305^{* * *}$ & $0.311^{* * *}$ & $0.329^{* * *}$ & - & - & - \\
& $(0.031)$ & $(0.031)$ & $(0.035)$ & & & \\
& {$[0.000]$} & {$[0.000]$} & {$[0.000]$} & & & \\
REMAIN MP & $0.264^{* * *}$ & $0.256^{* * *}$ & $0.264^{* * *}$ & $0.346^{* * *}$ & $0.329^{* * *}$ & $0.341^{* * *}$ \\
& $(0.036)$ & $(0.035)$ & $(0.034)$ & $(0.045)$ & $(0.046)$ & $(0.044)$ \\
& {$[0.000]$} & {$[0.000]$} & {$[0.000]$} & {$[0.000]$} & {$[0.000]$} & {$[0.000]$} \\
JUNIOR MP & $0.122^{* * *}$ & $0.099^{* *}$ & $0.146^{* * *}$ & $0.143 * * *$ & $0.115^{* * *}$ & $0.174^{* * *}$ \\
& $(0.038)$ & $(0.039)$ & $(0.047)$ & $(0.045)$ & $(0.049)$ & $(0.062)$ \\
& {$[0.001]$} & {$[0.011]$} & {$[0.002]$} & {$[0.002]$} & {$[0.019]$} & {$[0.006]$} \\
LEAVE VOTE SHARE & 0.0001 & $-0.081^{* *}$ & $-0.069^{*}$ & -0.005 & $-0.102^{* *}$ & $-0.085^{*}$ \\
& $(0.016)$ & $(0.034)$ & $(0.037)$ & $(0.023)$ & $(0.045)$ & $(0.048)$ \\
& {$[0.993]$} & {$[0.018]$} & {$[0.063]$} & {$[0.842]$} & {$[0.023]$} & {$[0.078]$} \\
Vote dummies & Yes & Yes & Yes & Yes & Yes & Yes \\
Const. controls & No & Yes & Yes & No & Yes & Yes \\
MP controls & No & No & Yes & No & No & Yes \\
N & 941 & 941 & 941 & 662 & 662 & 662 \\
$R^{2}$ & 0.30 & 0.32 & 0.33 & 0.26 & 0.28 & 0.30 \\
\hline
\end{tabular}

The table reports the results from a linear probability model estimated with Ordinary Least Squares (OLS) on the sample of all Conservative MPs (panel A) and for the sample of backbench MPs (panel B). The dependent variable (VOTE) is a binary variable equal to one whenever an MP voted in support of the Withdrawal Agreement and zero when the MP rebelled by voting against. REMAIN MP is a binary variable equal to one if the MP voted for remaining within the EU in the 2016 referendum; JUNIOR MP is a binary variable equal to one if the MP was elected to the House of Commons either in 2015 or 2017; LEAVE VOTE SHARE is the standardized share of voters who voted Leave in the referendum in 2016 in each constituency; and FRONTBENCH is a binary variable equal to one if the MP holds a position in government. All specifications include vote dummies. Constituency controls include population size, the unemployment rate, the share of constituents working in the public sector, the share of constituents with a higher education degree, and the share of constituents who are of working age. MP controls include gender, age, an index of the MP's history of rebellion, and the MP's win margin in the last election. Standard errors (in round brackets) are clustered at the constituency level; $p$ values are given in [square brackets]; ${ }^{*} p<0.10,{ }^{* *} p<0.05$, ${ }^{* * *} p<0.01$ 
Table 12 The probability of voting for the Withdrawal Agreement in the three Meaningful Votes combined (Probit coefficients)

\begin{tabular}{|c|c|c|c|c|}
\hline \multirow[t]{3}{*}{ Outcome: VOTE } & \multicolumn{3}{|c|}{ Backbencher sample } & \multirow{2}{*}{$\begin{array}{l}\text { Full sample } \\
\text { (4) }\end{array}$} \\
\hline & (1) & (2) & (3) & \\
\hline & Probit & Probit & Probit & OLS \\
\hline FRONTBENCH & - & - & - & $\begin{array}{l}0.329 * * * \\
(0.035) \\
{[0.000]}\end{array}$ \\
\hline REMAIN MP & $\begin{array}{l}1.14 * * * \\
(0.170) \\
{[0.000]}\end{array}$ & $\begin{array}{l}1.12 * * * \\
(0.174) \\
{[0.000]}\end{array}$ & $\begin{array}{l}1.22 * * * \\
(0.170) \\
{[0.000]}\end{array}$ & $\begin{array}{l}0.264 * * * \\
(0.034) \\
{[0.000]}\end{array}$ \\
\hline JUNIOR MP & $\begin{array}{l}0.533 * * * \\
(0.165) \\
{[0.001]}\end{array}$ & $\begin{array}{l}0.433 * * \\
(0.181) \\
{[0.017]}\end{array}$ & $\begin{array}{l}0.695 * * * \\
(0.231) \\
{[0.003]}\end{array}$ & $\begin{array}{l}0.146 * * * \\
(0.047) \\
{[0.002]}\end{array}$ \\
\hline LEAVE VOTE SHARE & $\begin{array}{l}-0.005 \\
(0.083) \\
{[0.949]}\end{array}$ & $\begin{array}{l}-0.447 * * \\
(0.0187) \\
{[0.017]}\end{array}$ & $\begin{array}{l}-0.439 * * \\
(0.212) \\
{[0.038]}\end{array}$ & $\begin{array}{l}-0.069 * \\
(0.037) \\
{[0.035]}\end{array}$ \\
\hline Vote dummies & Yes & Yes & Yes & Yes \\
\hline Const. controls & No & Yes & Yes & Yes \\
\hline MP controls & No & No & Yes & Yes \\
\hline $\mathrm{N}$ & 662 & 662 & 662 & 941 \\
\hline (Pseudo-)R2 & 0.22 & 0.25 & 0.27 & 0.33 \\
\hline
\end{tabular}

Columns (1)-(3) report Probit estimates (rather than marginal effects) for the sample of Conservative backbenchers and column (4) reports OLS estimates for the sample of all Conservative MPs. The dependent variable $(V O T E)$ is a binary variable equal to one whenever an MP voted in support of the Withdrawal Agreement and zero when the MP rebelled by voting against. REMAIN MP is a binary variable equal to one if the MP voted for remaining within the EU in the 2016 referendum; JUNIOR MP is a binary variable equal to one if the MP was elected to the House of Commons either in 2015 or 2017; LEAVE VOTE SHARE is the standardized share of voters who voted Leave in the referendum in 2016 in each constituency; and FRONT$B E N C H$ is a binary variable equal to one if the MP holds a position in government. All specifications include vote dummies. Constituency controls include population size, the unemployment rate, the share of constituents working in the public sector, the share of constituents with a higher education degree, and the share of constituents who are of working age. MP controls include gender, age, an index of the MP's history of rebellion, and the MP's win margin in the last election. Standard errors (in round brackets) are clustered at the constituency level; $p$ values are given in [square brackets]; ${ }^{*} p<0.10,{ }^{* *} p<0.05,{ }^{* * *} p<0.01$ 
Table 13 Breakdown of Meaningful Votes by Party and Government Positions (Alternative Affiliation Definition)

\begin{tabular}{|c|c|c|c|c|c|c|c|c|c|}
\hline & \multicolumn{3}{|c|}{ First vote } & \multicolumn{3}{|c|}{ Second vote } & \multicolumn{3}{|c|}{ Third vote } \\
\hline & For & Against & Abstain & For & Against & Abstain & For & Against & Abstain \\
\hline \multicolumn{10}{|c|}{ Panel A-Vote by Party } \\
\hline Conservative & 196 & 118 & 3 & 235 & 75 & 4 & 277 & 34 & 3 \\
\hline Labour & 3 & 248 & 5 & 3 & 238 & 5 & 5 & 234 & 7 \\
\hline LD & 0 & 11 & 0 & 0 & 11 & 0 & 0 & 11 & 0 \\
\hline SNP & 0 & 35 & 0 & 0 & 35 & 0 & 0 & 34 & 1 \\
\hline DUP & 0 & 10 & 0 & 0 & 10 & 0 & 0 & 10 & 0 \\
\hline Other & 3 & 10 & 8 & 4 & 22 & 8 & 4 & 21 & 9 \\
\hline Total & 202 & 432 & 16 & 242 & 391 & 17 & 286 & 344 & 20 \\
\hline \multicolumn{10}{|c|}{ Panel B-Conservatives by Govt. Position } \\
\hline Frontbench & 93 & 0 & 2 & 93 & 0 & 2 & 93 & 0 & 2 \\
\hline Backbench & 103 & 118 & 1 & 142 & 75 & 2 & 184 & 34 & 1 \\
\hline Total & 196 & 118 & 3 & 235 & 75 & 4 & 277 & 34 & 3 \\
\hline
\end{tabular}

This table shows the distribution of votes across the three Meaningful Votes taking into account that three Conservative MPs and seven Labour MPs resigned and became independent between the first and the second Meaningful Vote

Table 14 The probability of voting for the Withdrawal Agreement in the three Meaningful Votess separately (alternative affiliation definition)

\begin{tabular}{|c|c|c|c|c|c|}
\hline \multirow[t]{2}{*}{ Outcome: VOTE } & (1) & (2) & (3) & (4) & (5) \\
\hline & 1st Vote & 2nd Vote & 3rd Vote & Pooled & Diff. $p$-value \\
\hline \multirow[t]{3}{*}{ REMAIN MP } & $0.556^{* * * *}$ & $0.411 * * *$ & $0.164 * * *$ & $0.404 * * *$ & \multirow[t]{3}{*}{0.000} \\
\hline & $(0.061)$ & $(0.058)$ & $(0.043)$ & $(0.047)$ & \\
\hline & {$[0.000]$} & {$[0.000]$} & {$[0.000]$} & {$[0.000]$} & \\
\hline \multirow[t]{3}{*}{ JUNIOR MP } & $0.327 * * *$ & $0.211 * *$ & $0.104 * *$ & $0.223 * * *$ & \multirow[t]{3}{*}{0.026} \\
\hline & $(0.103)$ & $(0.085)$ & $(0.049)$ & $(0.068)$ & \\
\hline & {$[0.002]$} & {$[0.013]$} & {$[0.031]$} & {$[0.001]$} & \\
\hline \multirow[t]{3}{*}{ LEAVE VOTE SHARE } & -0.150 & $-0.152^{*}$ & $-0.106^{*}$ & $-0.144 * *$ & \multirow[t]{3}{*}{0.371} \\
\hline & $(0.121)$ & $(0.086)$ & $(0.057)$ & $(0.071)$ & \\
\hline & {$[0.217]$} & {$[0.077]$} & {$[0.066]$} & {$[0.044]$} & \\
\hline Vote dummies & No & No & No & Yes & - \\
\hline Controls & Yes & Yes & Yes & Yes & - \\
\hline $\mathrm{N}$ & 221 & 217 & 218 & 656 & - \\
\hline Pseudo-R2 & 0.31 & 0.24 & 0.17 & 0.29 & - \\
\hline
\end{tabular}

Columns (1) to (3) report the results corresponding to Table 4 on a sample that including only MPs that were officially part of the Conservative party at the time of each vote. This, therefore, takes into account that three Conservative MPs resigned between the first and the second Meaningful Vote (see Table 13). We observe that this makes almost no difference to the results, except in the second Meaningful Vote where LEAVE VOTE SHARE is imprecisely estimated with a $p$-value of $12 \%$. Column (4) reports the results for the combined sample (but in the second and third Meaningful Vote without the three MPs who resigned), corresponding to Table 3, column (3). We see that the results are very similar; $* p<0.10$, ** $p<0.05$, *** $p<0.01$ 


\section{References}

Aidt, T. S., \& Franck, R. (2013). How to get the snowball rolling and extend the franchise: Voting on the Great Reform Act of 1832. Public Choice, 155(3), 229-250.

Aidt, T. S., \& Franck, R. (2019). What motivates and oligarchic elite to democratize? Evidence from the roll call vote on the great reform act of 1832. Journal of Economic History, 79(3), 1-35.

Aidt, T. S., Castro, V., \& Martins, R. (2018). Shades of red and blue: Government ideology and sustainable development. Public Choice, 175(3), 303-323.

Alabrese, E., Becker, S. O., Fetzer, T., \& Novy, D. (2019). Who voted for brexit? Individual and regional data combined. European Journal of Political Economy, 56, 132-150.

Arnorsson, A., \& Zoega, G. (2018). On the causes of Brexit. European Journal of Political Economy, 55, 301-323.

Baughman, J. (2004). Party, constituency, and representation: Votes on abortion in the British House of Commons. Public Choice, 120(1), 63-85.

Becker, S. O., Fetzer, T., \& Novy, D. (2017). Who voted for Brexit? A comprehensive district-level analysis. Economic Policy, 32(92), 601-650.

Benedetto, G., \& Hix, S. (2007). The rejected, the ejected, and the dejected: Explaining government rebels in the 2001-2005 British House of Commons. Comparative Political Studies, 40(7), 755-781.

Bernholz, P., Schneider, F., Vaubel, R., \& Vibert, F. (2004). An alternative constitutional treaty for the European Union. Public Choice, 118(3-4), 451-468.

Bertelli, A. M., \& Dolan, R. M. (2009). The demand and supply of parliamentary policy advocacy: Evidence from UK health policy, 1997-2005. Government and Opposition, 44(3), 219-242.

Campbell, R., Cowley, P., Vivyan, N., \& Wagner, M. (2019). Legislator dissent as a valence signal. British Journal of Political Science, 49(1), 105-128.

Carey, J. M. (2008). Legislative voting and accountability., Cambridge Studies in Comparative Politics Cambridge: Cambridge University Press.

Clarke, H., Whiteley, P., Borges, W., Sanders, D., \& Stewart, M. (2016). Modelling the dynamics of support for a right-wing populist party: The case of UKIP. Journal of Elections, Public Opinion and Parties, 26(2), 135-154.

Clarke, H. D., Goodwin, M., \& Whiteley, P. (2017). Brexit: Why Britain voted to leave the European Union. Cambridge: Cambridge University Press.

Crowe, E. (1986). The web of authority: Party loyalty and social control in the British House of Commons. Legislative Studies Quarterly, 11(2), 161-185.

Dewan, T., \& Spirling, A. (2011). Strategic opposition and government cohesion in westminster democracies. The American Political Science Review, 105(2), 337-358.

Eggers, A. C., \& Spirling, A. (2016). Party cohesion in Westminster systems: Inducements, replacement and discipline in the House of Commons, 1836-1910. British Journal of Political Science, 46(3), 567-589.

Eggers, A. C., \& Spirling, A. (2018). The shadow cabinet in Westminster systems: Modeling opposition agenda setting in the House of Commons, 1832-1915. British Journal of Political Science, 48(2), $343-367$.

Fetzer, T. (2019). Did austerity cause Brexit? American Economic Review. Forthcoming.

Fidrmuc, J., Hulenyi, M., \& Tunali, C. B. (2019). Can money buy EU love? European Journal of Political Economy,. https://doi.org/10.1016/j.ejpoleco.2019.07.002.

Fox, S., \& Pearce, S. (2018). The generational decay of Euroscepticism in the UK and the EU referendum. Journal of Elections, Public Opinion and Parties, 28(1), 19-37.

Gaines, B. J., \& Garrett, G. (1993). The calculus of dissent: Party discipline in the British Labour government, 1974-1979. Political Behavior, 15(2), 113-135.

Hanretty, C. (2017). Areal interpolation and the UK's referendum on EU membership. Journal of Elections, Public Opinion and Parties, 27(4), 466-483.

Heath, O., \& Goodwin, M. (2017). The 2017 general election, Brexit and the return to two-party politics: An aggregate-level analysis of the result. The Political Quarterly, 88(3), 345-358.

Hix, S., Noury, A. G., \& Roland, G. (2007). Democratic Politics in the European Parliament. Themes in European Governance. Cambridge: Cambridge University Press.

Johnston, R., Cowley, P., Pattie, C., \& Stuart, M. (2002). Voting in the house or wooing the voters at home: Labour MPs and the 2001 general election campaign. The Journal of Legislative Studies, 8(2), 9-22.

Kam, C. J. (2009). Party discipline and parliamentary politics. Cambridge: Cambridge University Press.

Kam, C. J. (2014). Party discipline. In S. Martin, T. Saalfeld, \& K. W. Strom (Eds.), The Oxford handbook of legislative studies, Chapter 19 (pp. 1-21). Oxford: Oxford University Press. 
Kauder, B., \& Porafke, N. (2019). Conservative politicians and voting on same-sex marriage. German Economic Review. https://doi.org/10.1111/geer.12183.

Kauder, B., Potrafke, N., \& Riem, M. (2017). Do parties punish MPs for voting against the party line? CESifo Economic Studies, 63(3), 317-332.

Kirkland, J. H., \& Slapin, J. B. (2018). Roll call rebels: Strategic dissent in the United States and United Kingdom. Elements in American Politics. Cambridge: Cambridge University Press.

Krehbiel, K. (1993). Where's the party? British Journal of Political Science, 23(2), 235-266.

Lewis-Beck, M. S., \& Stegmaier, M. (2013). The VP-function revisited: A survey of the literature on vote and popularity functions after over 40 years. Public Choice, 157(3), 367-385.

Longley, N. (1998). Legislative systems with absolute party discipline: Implications for the agency theory approach to the constituent-legislator link. Public Choice, 97(1), 121-141.

Mood, C. (2010). Logistic regression: Why we cannot do what we think we can do, and what we can do about it. European Sociological Review, 26(1), 67-82.

Morgenstern, S. (2003). Patterns of legislative politics: Roll-Call voting in Latin America and the United States. Cambridge: Cambridge University Press.

Muller, W., \& Strom, K. (1999). Policy, office, or votes? How political parties in Western Europe make hard decisions. Cambridge Studies in Comparative Politics. Cambridge: Cambridge University Press.

Nannestad, P., \& Paldam, M. (1994). The VP-function: A survey of the literature on vote and popularity functions after 25 years. Public Choice, 79(3), 213-245.

Pattie, C., Fieldhouse, E., \& Johnston, R. J. (1994). The price of conscience: The electoral correlates and consequences of free votes and rebellions in the British House of Commons, 1987-92. British Journal of Political Science, 24(3), 359-380.

Ragusa, J. M. (2016). Partisan cohorts, polarization, and the Gingrich senators. American Politics Research, 44(2), 296-325.

Saiegh, S. M. (2011). Ruling by statute: How uncertainty and vote buying shape lawmaking. Cambridge: Cambridge University Press.

Schonhardt-Bailey, C. (2006). From the corn laws to free trade. Interests, ideas, and institutions in historical perspective. Cambridge, MA: MIT Press.

Sowemimo, M. (1996). The Conservative Party and European integration 1988-95. Party Politics, 2(1), 77-97.

Stratmann, T. (2006). Party-line voting and committee assignments in the German mixed-member system. In R. D. Congleton \& B. Swedenborg (Eds.), Democratic constitutional design and public policy. Analysis and evidence, Chapter 4 (pp. 111-130). Cambridge, MA: MIT Press.

Vivyan, N., \& Wagner, M. (2012). Do voters reward rebellion? The electoral accountability of MPs in Britain. European Journal of Political Research, 51(2), 235-264.

Zhang, A. (2018). New findings on key factors influencing the UK's referendum on leaving the EU. World Development, 102, 304-314.

Publisher's Note Springer Nature remains neutral with regard to jurisdictional claims in published maps and institutional affiliations. 